\title{
Impacts of MJO Convection over the Maritime Continent on Eastern China Cold Temperatures
}

\author{
LEI SONG \\ Center for Monsoon System Research, Institute of Atmospheric Physics, \\ Chinese Academy of Sciences, Beijing, China \\ RENGUANG WU \\ Center for Monsoon System Research, and State Key Laboratory of Numerical Modeling for \\ Atmospheric Sciences and Geophysical Fluid Dynamics, Institute of Atmospheric Physics, \\ Chinese Academy of Sciences, Beijing, China
}

(Manuscript received 21 August 2018, in final form 3 March 2019)

\begin{abstract}
The present study shows that winter cold events over eastern China can be induced by Madden-Julian oscillation (MJO)-associated anomalous convection over the Maritime Continent. We conduct composite analysis separately for identified intraseasonal cold events over eastern China that occur following anomalous convection over the Maritime Continent and the tropical Indian Ocean. For cold events related to anomalous convection over the Maritime Continent, the southward intrusion of cold air into eastern China takes an eastward path in association with an eastward location of an anomalous Siberian high compared to cold events related to anomalous convection over the tropical Indian Ocean. The Maritime Continent convection-related cold events tend to occur with a negative Arctic Oscillation (AO), whereas the relationship between the tropical Indian Ocean convection-related cold events and the AO is weak. Anomalous convective heating over the Maritime Continent triggers a poleward Rossby wave train, which, together with an AO-related southward wave train from northern Eurasia, contributes to the deepening of the East Asian trough. The poleward wave energy dispersion is similarly triggered by anomalous convective heating over the tropical Indian Ocean. In both types of cold events, anomalous tropical heating induces a meridional vertical circulation, with large-scale airmass convergence in the upper midtroposphere and descending of air on the northern branch of the vertical cell over Siberia. The upper-level mass convergence and the radiative cooling over Siberia work together for the enhancement and southeastward expansion of the Siberian high and the southward intrusion of cold anomalies to eastern China.
\end{abstract}

\section{Introduction}

East Asia is subject to frequent cold events during boreal winter. The long-lasting cold event in January and early February 2008 caused large economic and life losses in eastern China (Zhou et al. 2009; Wen et al. 2009). In December 2009, several cold events occurred in the United States, Europe, and East Asia, bringing grave damage to these regions (Wang and Chen 2010). A strong cold event struck East Asia in January 2016, causing snowfall and frigid weather in many regions (Song and $\mathrm{Wu}$ 2017).

The occurrence of cold events over East Asia is related to mid- and high-latitude circulation systems.

Corresponding author: Renguang Wu, renguang@mail.iap.ac.cn
The formation, intensification, and southeastward extending of the Siberian high and the accompanying cold air advection contribute to the occurrence of cold events over East Asia (Ding and Krishnamurti 1987; Ding 1990; Zhang et al. 1997; Jeong and Ho 2005; Bueh et al. 2011; Shoji et al. 2014; Song and Wu 2017). The cold events tend to follow the deepening of the East Asian trough. The southeastward flow to the rear of the East Asian trough favors the southward intrusion of cold air, leading to the invasion of cold events to eastern China (Zhang et al. 1997; Jeong and Ho 2005; Takaya and Nakamura 2005a,b; Bueh et al. 2011; Song et al. 2016; Song and Wu 2017). The development of the Siberian high and the East Asian trough is closely related to the Rossby wave trains propagating along the polar front jet and the subtropical jet (Watanabe 2004; Takaya and Nakamura 2005a,b; 
Song et al. 2016; Song and Wu 2017). The Arctic Oscillation (AO) (Thompson and Wallace 1998, 2000) can induce cold events over East Asia through the modification of the Siberian high, the tropospheric Rossby wave train, and the polar front jet (Gong et al. 2001; Wu and Wang 2002; Jeong and Ho 2005; Park et al. 2010; Park et al. 2011). Both positive and negative phases of the AO may be followed by cold events over eastern China on intraseasonal time scale (Song and $\mathrm{Wu} 2018$ ).

The Madden-Julian oscillation (MJO) is the most prominent system among the intraseasonal oscillations in the tropics. It is manifested as eastward propagation of zonal wavenumber 1 on a time scale of 30-60 days (Madden and Julian 1971, 1972; Lin and Brunet 2009). The tropical heating in association with the MJO can induce tropospheric Rossby wave trains (Jin and Hoskins 1995; Matthews et al. 2004). The MJO-induced Rossby wave train propagates poleward and changes the midand high-latitude circulation, and thus can affect the mid- and high-latitude climate (Yoo et al. 2012; Baxter et al. 2014; Seo et al. 2016). Lin and Brunet (2009) found that the positive temperature perturbation emerges over Canada 5-15 days after MJO phases 3 and 7. Yoo et al. (2012) indicates that the Arctic warming (cooling) is contributed by the enhanced (reduced) poleward Rossby wave energy dispersion related to MJO phase 5 (1).

The temperature anomalies over East Asia are shown to be related to the MJO. More cold surges happen over East Asia when the MJO is in phases 3 and 4 (Jeong and Ho 2005). He et al. (2011) indicated that the tropical heating related to the MJO can change local Hadley circulation and the equatorially trapped Rossby wave, and thus impact the temperature anomalies over East Asia. Seo et al. (2016) also noted the change in local Hadley circulation due to the tropical heating in association with the MJO phase 3, which plays a key role in the temperature variations over East Asia. Abdillah et al. (2018) studied the westward or eastward location of cold anomalies over East Asia and found that the location of cold anomalies is related to where the MJOrelated tropical heating is situated. These studies consistently showed the occurrence of cold anomalies over eastern China in association with the MJO convection over the tropical Indian Ocean. However, it is not clear if the tropical heating over the Maritime Continent can lead to robust cold anomalies over eastern China. In some studies, the main body of cold anomalies related to MJO phase 5 is situated off the coast of eastern China [see Figs. 4a to 4c of He et al. (2011) and Fig. 1e of Seo et al. (2016)]. In other studies, the cold anomalies are observed over northeastern China in MJO phase 5 [see Fig. 1 of Jeong and Ho (2005) and the right panel of Fig. 1 of Yoo et al. (2012)]. Thus, it is worthwhile to investigate the occurrence of the cold events over eastern China when the MJO convection is located over the Maritime Continent.

Our analysis shows that both cold and warm anomalies occur over eastern China corresponding to convection anomalies over the Maritime Continent. Figure 1 presents spatiotemporal evolution of intraseasonal (30-60 day) surface air temperature anomalies and outgoing longwave radiation (OLR) anomalies during two typical cold and warm temperature events over eastern China $\left(20^{\circ}-40^{\circ} \mathrm{N}, 100^{\circ}-120^{\circ} \mathrm{E}\right)$. During both events, negative OLR anomalies are located over the Maritime Continent. Intraseasonal cold anomalies developed over eastern China from 11 December to 20 December 1999 (Figs. 1a-d). The main body of the cold anomalies was situated over eastern China south of $40^{\circ} \mathrm{N}$ and the cold anomalies were evident over northeastern China after 11 December (Figs. 1b-d), which is in accordance with Jeong and Ho (2005) and Yoo et al. (2012). Cold anomalies were also observed off the coast of eastern China during the whole event (Figs. 1a-d), which corresponds to the findings of He et al. (2011) and Seo et al. (2016). The maximum of regional mean cold anomalies over eastern China $\left(20^{\circ}-40^{\circ} \mathrm{N}, 100^{\circ}-120^{\circ} \mathrm{E}\right)$ appeared about one week after the maximum of regional mean negative OLR anomalies over the Maritime Continent $\left(15^{\circ} \mathrm{S}-15^{\circ} \mathrm{N}\right.$, $110^{\circ}-160^{\circ} \mathrm{E}$ ) (Fig. 2a). The warm anomalies occurred over eastern China from 15 December to 24 December 1996, which appeared as a southward extension of the main body of warm anomalies over the midlatitudes (Figs. 1e-h). The warm anomalies over eastern China lagged the negative OLR anomalies over the Maritime Continent by about one week (Fig. 2b).

The fact that anomalous convection over the Maritime Continent is followed by both cold and warm anomalies over eastern China explains why the composite temperature anomalies over eastern China obtained with respect to the MJO phase 5 are weak in previous studies. Therefore, there is need to analyze intraseasonal anomalous temperature events one by one to identify those related to enhanced convection over the Maritime Continent and conduct composite analysis for these events. Since cold events are of more importance during boreal winter, our study is focused on intraseasonal cold events over eastern China related to the Maritime Continent convection. The cold events in association with the enhanced convection over the tropical Indian Ocean are also investigated for comparison. The two issues to be addressed are what are the spatial-temporal features associated with the two types of cold events and what are the dynamical processes linking the tropical convection to eastern China cold events. The time-lag relationship between the MJO-related convection anomalies and 
(a) $11 / \mathrm{DEC} / 1999$

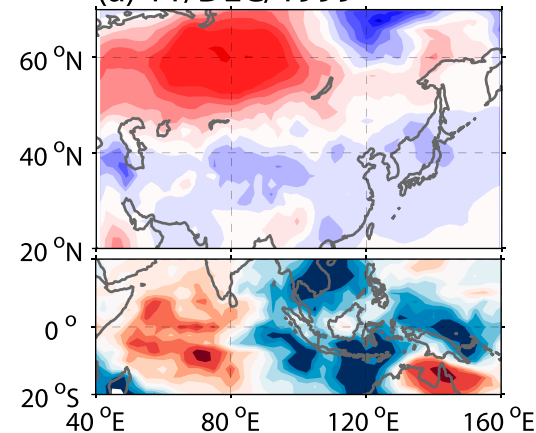

(b) $14 / \mathrm{DEC} / 1999$
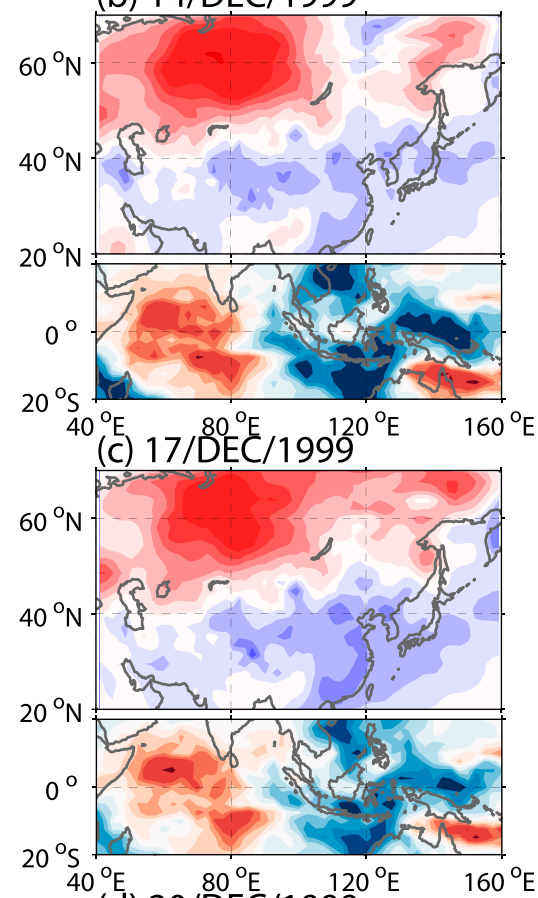

$\left.{ }^{40}{ }^{\circ} \mathrm{E}\right) 20 / \mathrm{B} 0^{\circ} \mathrm{E} / 199^{120} 9^{\circ}$

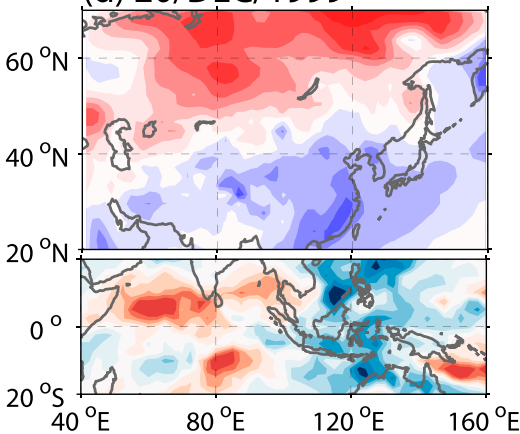

(e) $15 / \mathrm{DEC} / 1996$

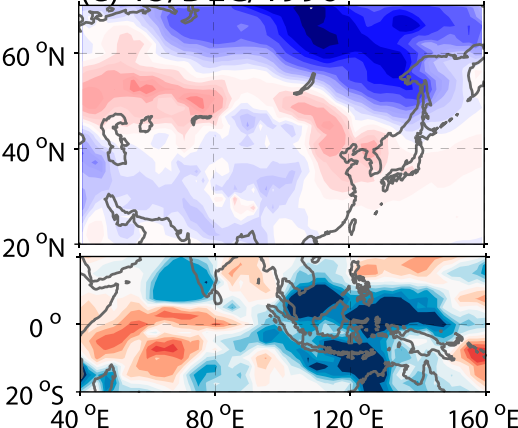

(f) $18 / \mathrm{DEC} / 1996$

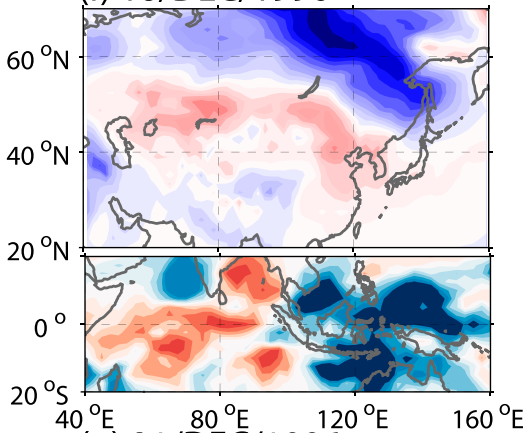

(q) $21 / \mathrm{DEC} / 1996$

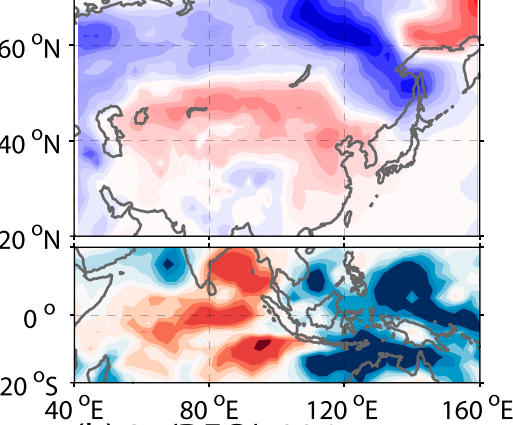

(h) $24 / \mathrm{DEC} / 1996$

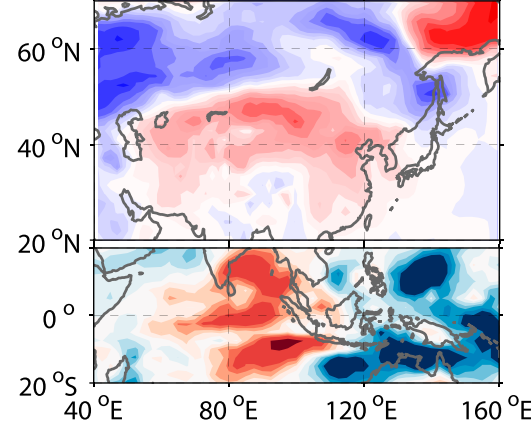

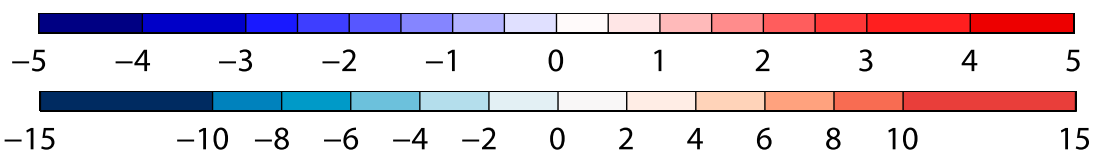

FIG. 1. Surface air temperature anomalies (shading; ${ }^{\circ} \mathrm{C}$ ) from $20^{\circ}$ to $70^{\circ} \mathrm{N}$ and OLR anomalies (shading; $\mathrm{W} \mathrm{m}^{-2}$ ) between $20^{\circ} \mathrm{S}$ and $20^{\circ} \mathrm{N}$ during (a)-(d) 11-20 Dec 1999 and (e)(h) 15-24 Jan 1996. The upper color bar is for the temperature anomalies and the lower color bar is for the OLR anomalies. 
(a) $1998 / 1999$
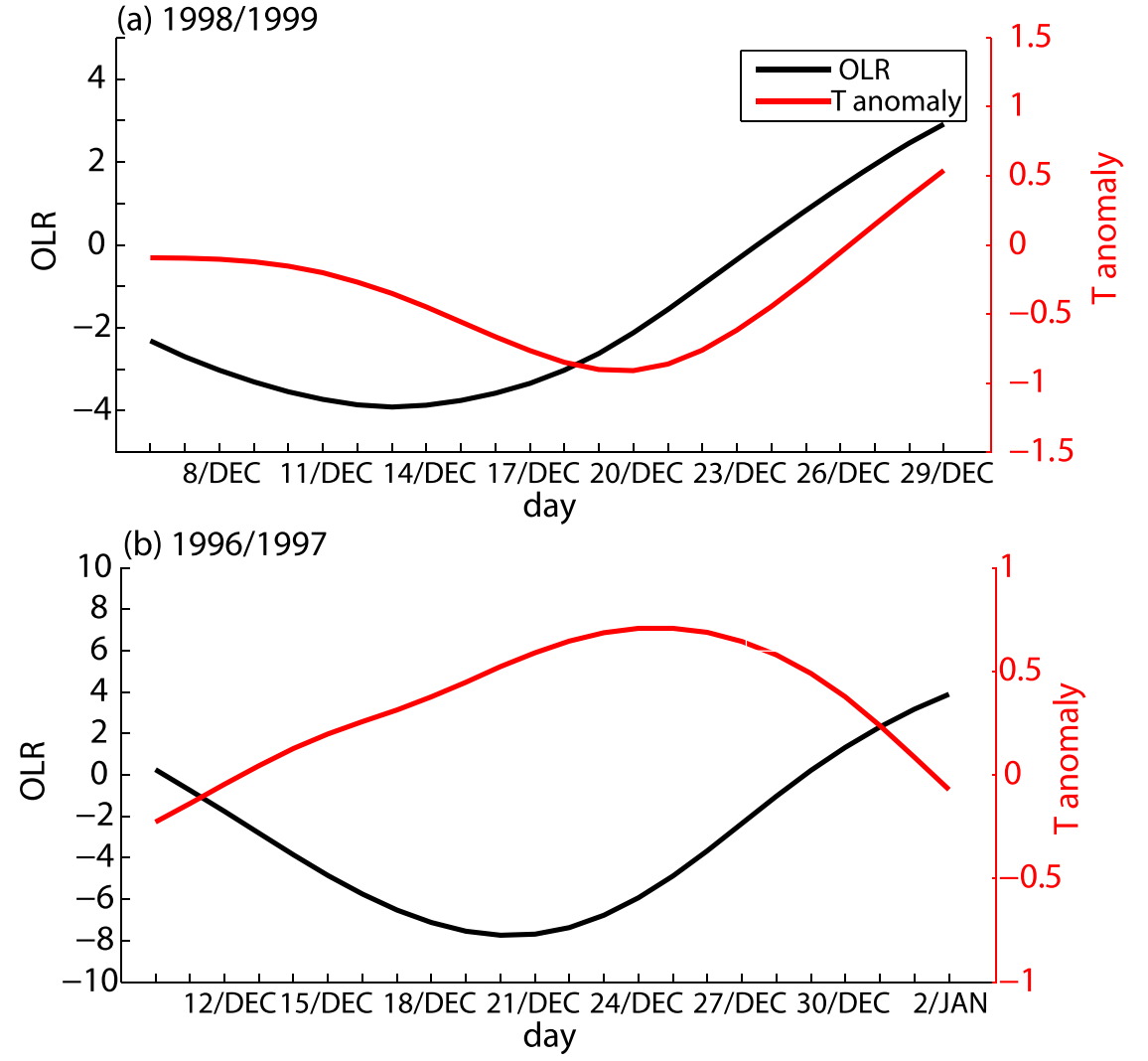

FIG. 2. Time evolution of surface air temperature anomalies $\left({ }^{\circ} \mathrm{C}\right)$ over the region $20^{\circ}-40^{\circ} \mathrm{N}$, $100^{\circ}-120^{\circ} \mathrm{E}$ (red curve) and OLR anomalies $\left(\mathrm{W} \mathrm{m}^{-2}\right.$ ) over the region $15^{\circ} \mathrm{S}-15^{\circ} \mathrm{N}, 110^{\circ}-160^{\circ} \mathrm{E}$ (black curve) during (a) 6-29 Dec 1998 and (b) 10 Dec 1996-2 Jan 1997.

intraseasonal cold events may improve the prediction skill of persisting low temperature events over eastern China (Lin and Brunet 2009; Lin 2015).

In the following, we describe in section 2 the dataset used in the present study and the method for identifying intraseasonal cold events over eastern China related to the convection anomalies over the tropical Indian Ocean and the Maritime Continent. In section 3, we analyze basic features of these two types of intraseasonal cold events. Possible dynamical mechanisms are investigated to explain the differences between these cold events in section 4. A summary and some discussions are provided in section 5 .

\section{Data and methodology}

The daily products from the National Centers for Environmental Prediction (NCEP)-Department of Energy (DOE) Reanalysis 2 provided by the NOAA/OAR/ ESRL/Physical Science Division (PSD) (Kanamitsu et al. 2002) are employed in this study. The variables used include surface air temperature, surface wind, sea level pressure, outgoing longwave radiation, geopotential height, and meridional and zonal winds at different levels.
The surface air temperature and wind are on the T62 Gaussian grid. The other variables are available on a horizontal resolution of $2.5^{\circ} \times 2.5^{\circ}$. The pressure levels extend from 1000 to $10 \mathrm{hPa}$ with 17 layers.

The daily AO index used in this study is obtained from the NOAA Climate Prediction Center (CPC) website (http://www.cpc.ncep.noaa.gov/products/precip/CWlink/ daily_ao_index/ao.shtml). The strength of the Siberian high is depicted by the area-mean sea level pressure averaged over the region $40^{\circ}-65^{\circ} \mathrm{N}, 80^{\circ}-120^{\circ} \mathrm{E}$ (Panagiotopoulos et al. 2005). The propagation of the Rossby wave train is illustrated by the Rossby wave activity fluxes (Takaya and Nakamura 2001). All the variables are filtered by the Butterworth bandpass filter to extract the 30-60-day intraseasonal variations. Composite analysis is performed for intraseasonal cold events over eastern China with a time lag with respect to the MJO convection anomalies over the tropical Indian Ocean and the Maritime Continent during boreal winters (December to February) from 1979/80 to 2015/16. The significance of the composite analysis is estimated by the Student's $t$ test.

The selection of the intraseasonal cold events over eastern China is based on the 30-60-day filtered regional 
mean temperature anomalies averaged over the region of $20^{\circ}-40^{\circ} \mathrm{N}, 100^{\circ}-120^{\circ} \mathrm{E}$. An intraseasonal cold event is recorded when the regional mean temperature anomaly exceeds $-\sigma$ (standard deviation), and the day of the maximum negative temperature anomaly is taken as reference (day 0). We identified 63 intraseasonal cold events over eastern China in the 37 winters (Table 1). To determine the intraseasonal cold events associated with the convection anomalies over the tropical Indian Ocean and the Maritime Continent, we analyze the time-lag relationship of regional temperature anomalies with regional mean OLR anomalies over the tropical Indian Ocean $\left(15^{\circ} \mathrm{S}-\right.$ $\left.15^{\circ} \mathrm{N}, 50^{\circ}-100^{\circ} \mathrm{E}\right)$ and the Maritime Continent $\left(15^{\circ} \mathrm{S}-\right.$ $15^{\circ} \mathrm{N}, 110^{\circ}-160^{\circ} \mathrm{E}$ ) starting from two weeks before day 0 of each cold event. The two-week time window is chosen as it takes about 10 days from the start to the peak of the cold anomalies in intraseasonal cold events and every phase of 30-60-day oscillation lasts about 4 to 7 days. If the peak of the regional mean OLR anomaly over the tropical Indian Ocean (the Maritime Continent) exceeds $-0.5 \sigma$, and the mean OLR anomaly over the Maritime Continent (the tropical Indian Ocean) does not exceed $-0.5 \sigma$, this intraseasonal cold event is categorized as an Indian Ocean (Maritime Continent) convection-related cold event. Among the 63 cold events, we identified 22 Indian Ocean (IO) and 16 Maritime Continent (MC) convection-related events (Table 1). The lead-lag composite analysis is then performed for these two types of cold events. We note that among the 16 identified MC convection-related cold events, 12 were preceded by negative AO. The AO signals during IO convection-related cold events are diverse, indicating a weak relationship between the AO and the IO convection-related cold events.

We also performed a composite analysis based on the phase of the cold events. Phase 1 is the day when the regional mean temperature anomalies over eastern China is in the transition from negative to positive value, phase 3 is the day when the regional mean temperature anomalies reach the largest negative value with the magnitude exceeding one standard deviation, and phase 2 is defined as the day located in the middle between phases 1 and 3 . The obtained temporal evolution of composite anomalies based on the phase of cold events is similar to that based on the lead-lag time. As there are more time slices in the composite based on the lead-lag days, we obtain clearer features of continuous evolution. Thus, we only show composite anomalies based on the lead-lag days.

\section{Features of the MC and IO convection-related cold events}

Temperature anomalies display different evolutions during MC and IO convection-related cold events.
TABLE 1 . The years and day 0 of the intraseasonal cold events over eastern China. The MC- and IO-related cold events are marked with a superscript asterisk $(*)$ and plus sign $(+)$, respectively. See the text for definition of the events.

\begin{tabular}{|c|c|c|c|}
\hline Year & Day 0 & Year & Day 0 \\
\hline $1979 / 80$ & 4 Jan; 6 Feb & $1997 / 98$ & 7 Dec; $22 \mathrm{Jan}^{+}$ \\
\hline $1980 / 81$ & $\begin{array}{l}25 \mathrm{Dec}^{*} ; 26 \mathrm{Jan}^{*} ; \\
25 \mathrm{Feb}^{*}\end{array}$ & $1998 / 99$ & $\begin{array}{l}6 \text { Dec; } 11 \text { Jan*; } \\
18 \text { Feb }^{*}\end{array}$ \\
\hline $1981 / 82$ & $9 \mathrm{Feb}$ & $1999 / 2000$ & $20 \mathrm{Dec}^{*} ; 27$ Jan \\
\hline $1982 / 83$ & $\begin{array}{l}7 \mathrm{Dec}^{*} ; 11 \mathrm{Jan}^{*} \\
20 \mathrm{Feb}^{+}\end{array}$ & $2001 / 02$ & $22 \mathrm{Dec} ; 28 \mathrm{Jan}^{+}$ \\
\hline $1983 / 84$ & $28 \mathrm{Dec}^{+} ; 1 \mathrm{Feb}$ & $2002 / 03$ & $31 \mathrm{Dec}^{+} ; 5 \mathrm{Feb}^{+}$ \\
\hline $1984 / 85$ & $25 \mathrm{Dec} ; 22 \mathrm{Feb}^{*}$ & $2003 / 04$ & $16 \mathrm{Dec}^{+} ; 25 \mathrm{Jan}$ \\
\hline $1985 / 86$ & $11 \mathrm{Dec} ; 26 \mathrm{Feb}^{*}$ & $2004 / 05$ & 31 Dec; 19 Feb \\
\hline $1987 / 88$ & 5 Dec; 16 Jan & $2005 / 06$ & $12 \mathrm{Dec}^{+}$ \\
\hline $1988 / 89$ & 10 Dec; 16 Jan & $2007 / 08$ & $5 \mathrm{Feb}^{+}$ \\
\hline $1989 / 90$ & $26 \mathrm{Dec}$ & $2008 / 09$ & $9 \mathrm{Jan}^{*}$ \\
\hline 1990/91 & 7 Jan; 20 Feb & $2009 / 10$ & $5 \mathrm{Jan} ; 14 \mathrm{Feb}^{+}$ \\
\hline $1991 / 92$ & $31 \mathrm{Dec}^{+} ; 11 \mathrm{Feb}^{+}$ & 2010/11 & $16 \mathrm{Jan}^{*}$ \\
\hline $1992 / 93$ & $19 \mathrm{Jan}^{+} ; 25 \mathrm{Feb}$ & $2011 / 12$ & $15 \mathrm{Dec}^{*}$ \\
\hline $1993 / 94$ & $17 \mathrm{Dec}^{+} ; 20 \mathrm{Jan}^{+}$ & $2012 / 13$ & $3 \mathrm{Jan}^{+} ; 14 \mathrm{Feb}^{+}$ \\
\hline $1994 / 95$ & $18 \mathrm{Dec}^{*} ; 1 \mathrm{Feb}^{*}$ & $2013 / 14$ & $23 \mathrm{Dec}^{*} ; 12 \mathrm{Feb}^{+}$ \\
\hline $1995 / 96$ & $21 \mathrm{Feb}^{+}$ & $2014 / 15$ & $14 \mathrm{Dec}^{3} 3 \mathrm{Feb}^{+}$ \\
\hline 1996/97 & 7 Jan; 12 Feb & $2015 / 16$ & $16 \mathrm{Dec}^{+} ; 24 \mathrm{Jan}^{+}$ \\
\hline
\end{tabular}

During MC convection-related cold events, weak negative temperature anomalies are observed to the north of the Lake Baikal on day -12 . Meanwhile, negative OLR anomalies develop over the eastern Indian Ocean and the Maritime Continent (Fig. 3a). With the enhancement and slow eastward movement of anomalous convection after day -12 , the cold anomalies intensify and move southward (Fig. 3b). The anomalous convection over the Maritime Continent is strongest on day -6 (Fig. 3c). The cold anomalies keep intensifying and moving southward to eastern China until day 0 (Figs. $3 \mathrm{c}-\mathrm{e}$ ). On day 0 , eastern China is covered by large negative temperature anomalies (Fig. 3e) and the distribution of temperature anomalies is similar to that corresponding to the strong south cold events identified by Song and $\mathrm{Wu}$ (2017). It should be noted that the cold anomalies also appear over northeastern China, which is in accordance with Jeong and Ho (2005). The peak of the temperature anomalies lags the peak of the OLR anomalies over the Maritime Continent by about 6 days, similar to the 1998/99 case shown in Figs. $1 \mathrm{a}-\mathrm{d}$ and $2 \mathrm{a}$. The cold anomalies over eastern China weaken after day 0 accompanying the switch of sign of OLR anomalies over the Maritime Continent (Figs. 3f-h).

On day -12 of IO convection-related cold events, cold anomalies extend northeastward from the Caspian Sea to the Lake Baikal (Fig. 4a). Anomalous convection is located over the tropical Indian Ocean, 

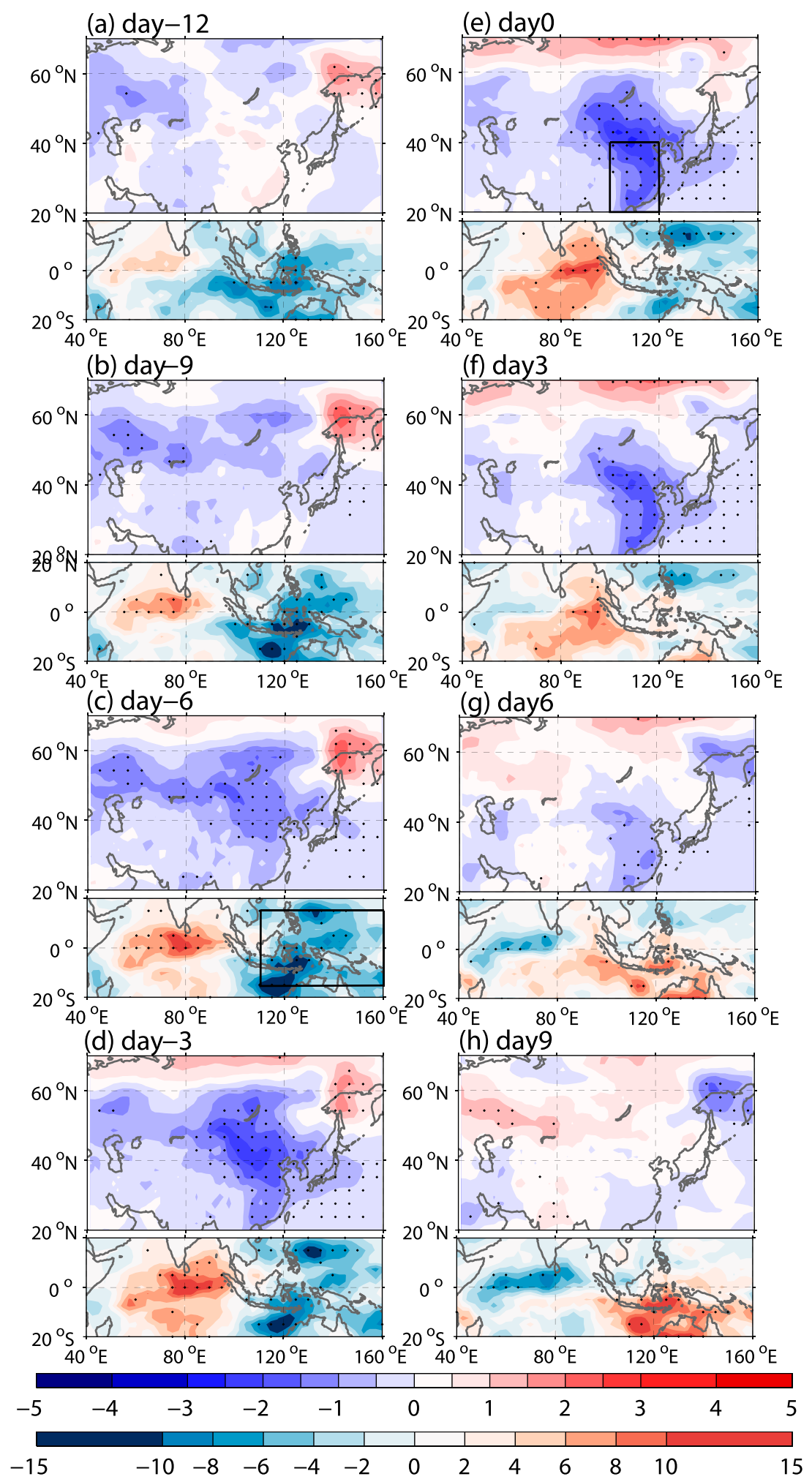

FIG. 3. Composite surface air temperature anomalies (shading; ${ }^{\circ} \mathrm{C}$ ) from $20^{\circ}$ to $70^{\circ} \mathrm{N}$ and OLR anomalies (shading; $\mathrm{W} \mathrm{m}^{-2}$ ) between $20^{\circ} \mathrm{S}$ and $20^{\circ} \mathrm{N}$ on days (a) -12 , (b) -9 , (c) -6 , (d) -3 , (e) 0 , (f) 3, (g) 6, and (h) 9 of MC convection-related intraseasonal cold events over eastern China. The upper color bar is for the temperature anomalies and the lower color bar is for the OLR anomalies. Black dots indicate anomalies significant at the $95 \%$ confidence level. Black boxes denote the regions where area-mean temperature and OLR anomalies are calculated in Fig. 7. 
(a) day -12

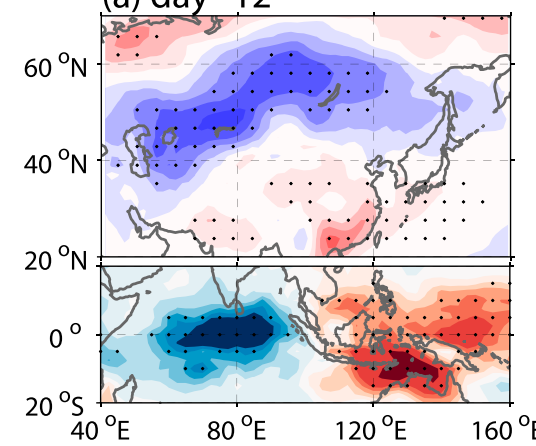

(b) day-9
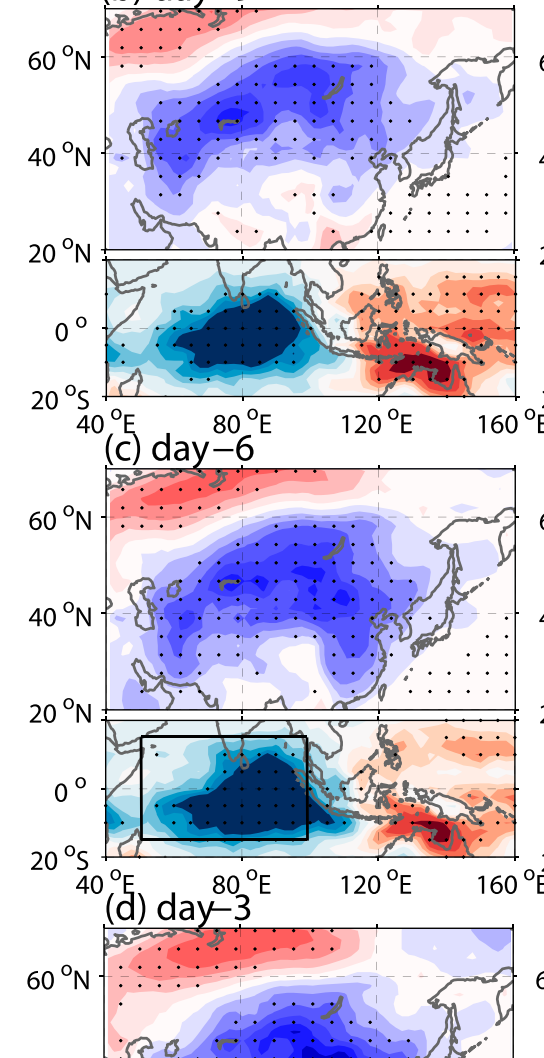

$40^{\circ} \mathrm{N}$
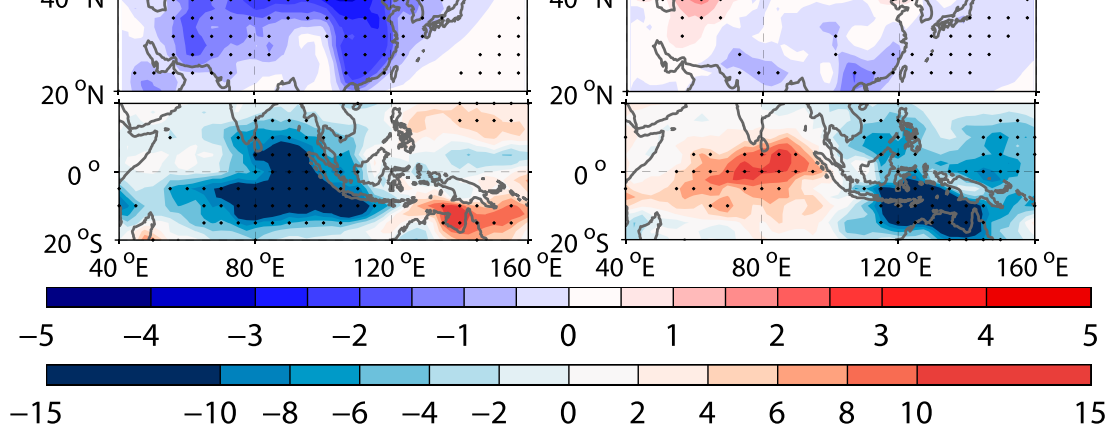

FIG. 4. As in Fig. 3, but for the IO convection-related intraseasonal cold events. (e) day 0
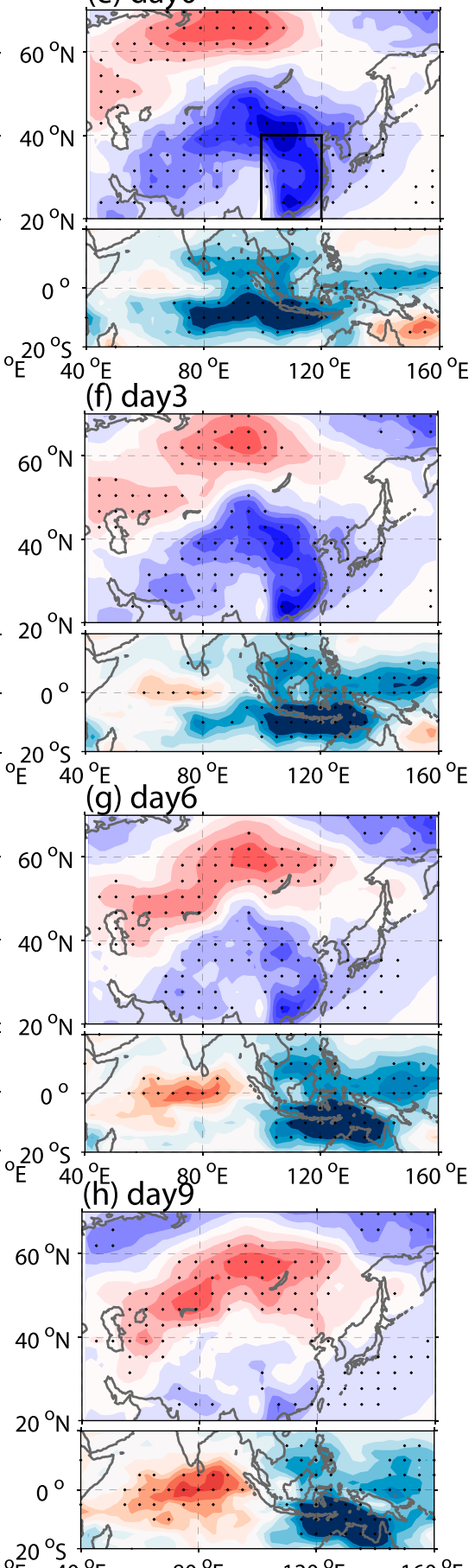

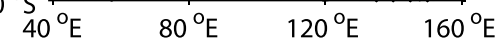


accompanied by positive OLR anomalies over the Maritime Continent. This west-east dipole structure of OLR anomalies appears similar to MJO phases 23 . In the following days, the cold anomalies move southeastward from the Lake Baikal to eastern China (Figs. 4b-d). Meanwhile, anomalous convection over the tropical Indian Ocean intensifies and propagates eastward and the positive OLR anomalies over the Maritime Continent weaken. On day 0, the cold anomalies over eastern China are strongest (Fig. 4e). The temperature anomaly pattern is similar to that of the MC convection-related cold events (Fig. 3e) but with larger anomalies. The anomalous convection reaches the Maritime Continent on day 0. It continues to move eastward afterward (Figs. 4e-h). At the same time, the cold anomalies are weakened over eastern China and move to the ocean.

The development of the cold anomalies over eastern China is closely related to cold air advection by surface wind anomalies, which is associated with the intensification and southward intrusion of the Siberian high (Song and Wu 2017). On day -12 of the MC convection-related cold events, surface anticyclonic anomalies are located north of Lake Baikal (Fig. 5a), which is in accordance with the location of cold anomalies (Fig. 3a). This suggests that the radiative cooling accompanying the anomalous anticyclone contributes to the accumulation of cold air over this region. This process helps the buildup of the Siberian high (Ding and Krishnamurti 1987). The anomalous anticyclone moves southward afterward (Figs. 5b,c). After day -6 , the anticyclonic anomalies intrude into eastern China, accompanied by strong anomalous northerly winds along the southeastern flank of the anomalous anticyclone, which brings the cold air toward eastern China (Figs. $5 \mathrm{c}-\mathrm{e}$ ). The northerly winds are evident along and off the east coast of China after day -6 , corresponding to the cold anomalies over the western Pacific (Figs. 3d,e). After day 0, the anomalous anticyclone and associated northerly winds continue moving southeastward and then weakening over the western Pacific (Figs. 5f-h).

The anticyclonic anomalies on day -12 during IO convection-related cold events are located westward compared to those during MC convection-related cold events (Figs. 5a and 6a). The anomalous anticyclone moves eastward afterward and it is located over western Siberia on day -6 (Fig. 6c). After intensifying over Siberia, the anomalous anticyclone intrudes southeastward, with obvious anomalous northerly winds to the southeastern flank of anomalous anticyclone. The southeastward expansion of the Siberian high leads to the development of cold anomalies over eastern China (Figs. 6d,e). Different from the MC convection-related cold events, the northerly winds are not evident over the western Pacific Ocean, so that the cold anomalies are weak over the sea (Figs. 4d,e). The anomalous anticyclone is weakened over eastern China after day 0 (Figs. $6 \mathrm{f}-\mathrm{h}$ ). The anomalous northerly winds move to the tropical western North Pacific, accompanied by cold anomalies there.

To illustrate the temporal relationship, we present in Fig. 7 the temporal evolutions of regional mean temperature anomalies over eastern China $\left(20^{\circ}-40^{\circ} \mathrm{N}\right.$, $\left.100^{\circ}-120^{\circ} \mathrm{E}\right)$, OLR anomalies over the Maritime Continent, the Siberian high index (Panagiotopoulos et al. 2005), and the AO index. For the MC convectionrelated cold events, the temperature anomalies reach the lowest maximum on day 0 , which lags the maximum negative OLR anomalies over the Maritime Continent by 7 days. This suggests a close relationship between anomalous convection over the Maritime Continent and the occurrence of cold events over eastern China. The intensification of the Siberian high leads the cold anomalies by 2 days, indicating an impact of the Siberian high through the southward advection of cold air (Ding and Krishnamurti 1987; Takaya and Nakamura 2013; Song and Wu 2017). Another thing to be noted is that the AO is in a negative phase during the developing stage of the MC convection-related cold events, which suggests a possible influence of the $\mathrm{AO}$ on the MC convectionrelated cold events. Therefore, the negative $\mathrm{AO}$ and the convection anomalies over the Maritime Continent may work together in the occurrence of MC convectionrelated cold events over eastern China.

For the IO convection-related cold events, the temperature anomalies over eastern China on day 0 are stronger than those for the MC convection-related cold events (Fig. 7b). The Siberian high leads the temperature anomalies by 3 days with its intensity weaker compared to the MC convection-related cold events. The OLR anomalies over the tropical Indian Ocean lead the cold anomalies by 7 days with the magnitude larger compared to the MC convectionrelated cold events. The AO index is weak during the analysis time period, which indicates that the AO may not play a role in the IO convection-related cold events.

For both the MC and IO convection-related cold events, the convection leads the Siberian high by about 5 days. This suggests that anomalous convection over the Maritime Continent and the tropical Indian Ocean may contribute to the enhancement of the Siberian high directly. Previous studies have 

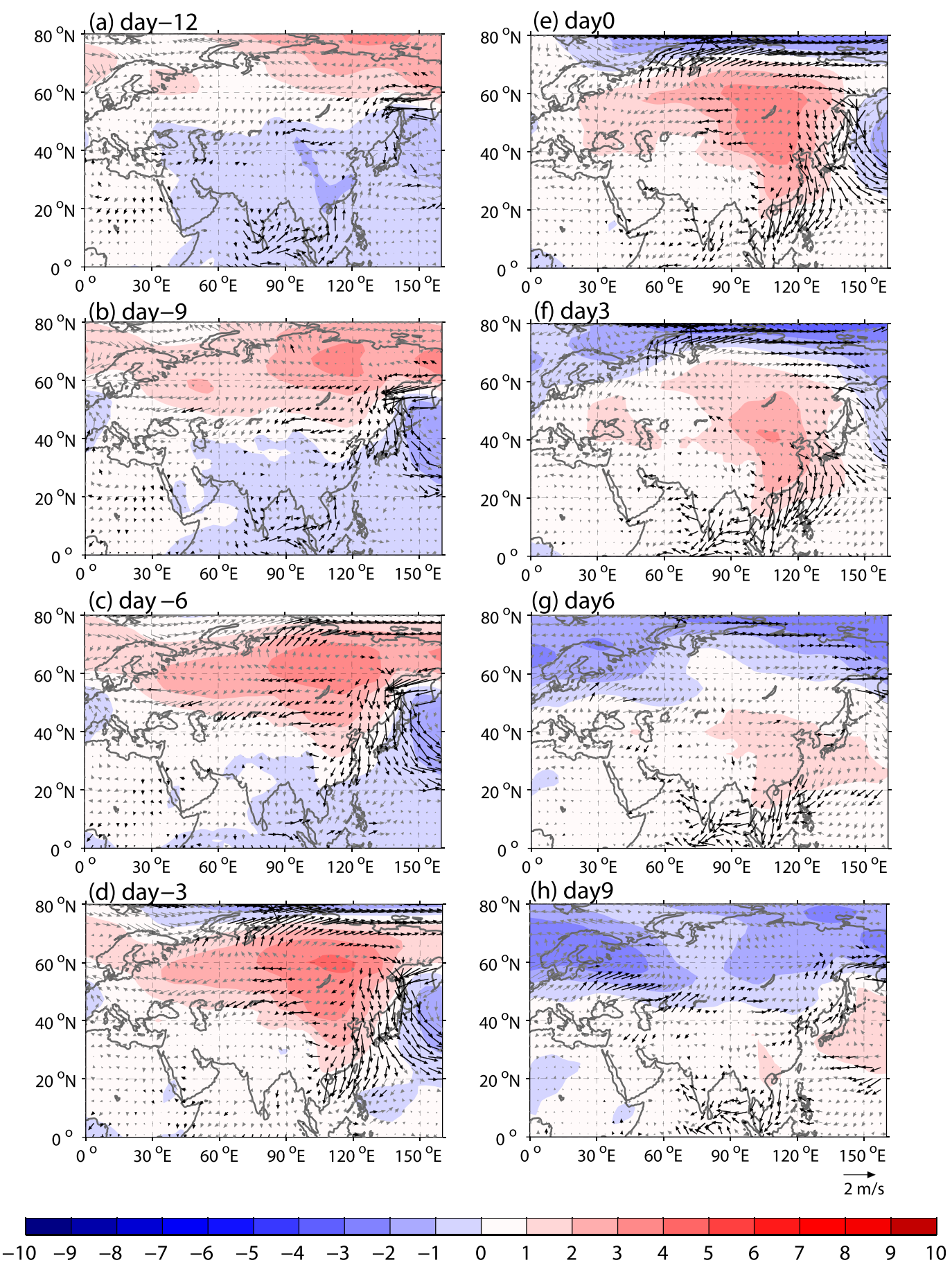

FIG. 5. Composite sea level pressure anomalies (shading; hPa) and surface wind anomalies (vector; scale on right bottom) on days (a) -12 , (b) -9 , (c) -6 , (d) -3 , (e) 0, (f) 3, (g) 6, and (h) 9 of MC convection-related intraseasonal cold events over eastern China. Black vectors denote wind anomalies significant at the $95 \%$ confidence level.

indicated that anomalous convective heating related to the MJO may modify the local Hadley circulation and influence the winter climate over East Asia (Wu et al. 2009; He et al. 2011; Seo et al. 2016). Is it possible that anomalous convective heating over the tropical Indian Ocean and the Maritime Continent induces anomalous ascending over the tropics and anomalous descending over Siberia and thus leads to 

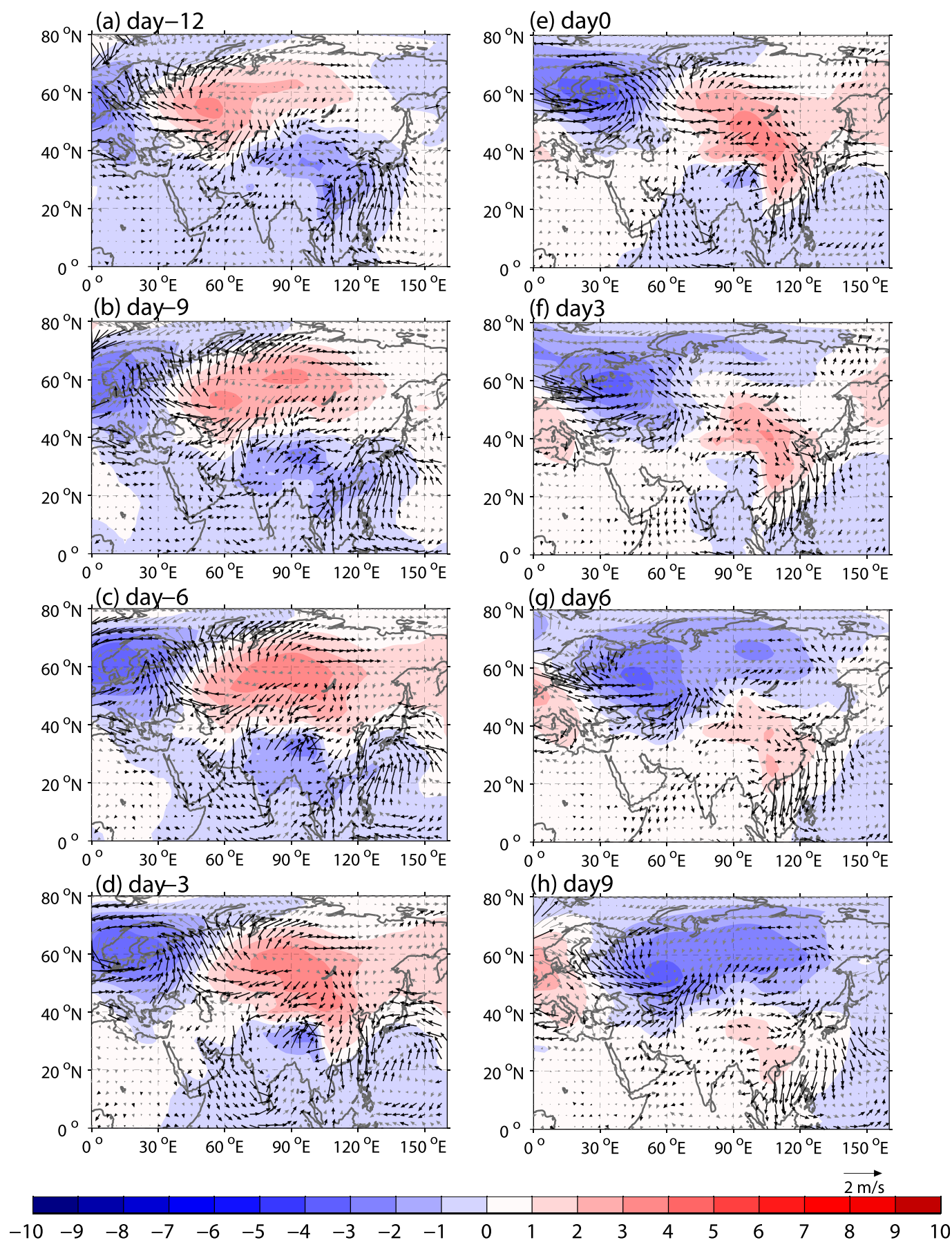

FIG. 6. As in Fig. 5, but for the IO convection-related cold events.

the intensification of the Siberian high? We will address this issue in the next section.

\section{Differences of circulation between the MC and IO convection-related cold events}

The tropospheric circulation anomalies show notable differences in association with the MC and IO convection-related cold events. For the MC convectionrelated cold events, three pairs of anomalous anticyclones and cyclones are observed along the subtropical waveguide at 300-hPa (Fig. 8a). The Rossby wave activity fluxes (Takaya and Nakamura 2001) emit from the anomalous anticyclone over southern Europe, indicating a downstream dispersion of wave energy along the subtropical jet. The above Rossby wave pattern is similar to that in 

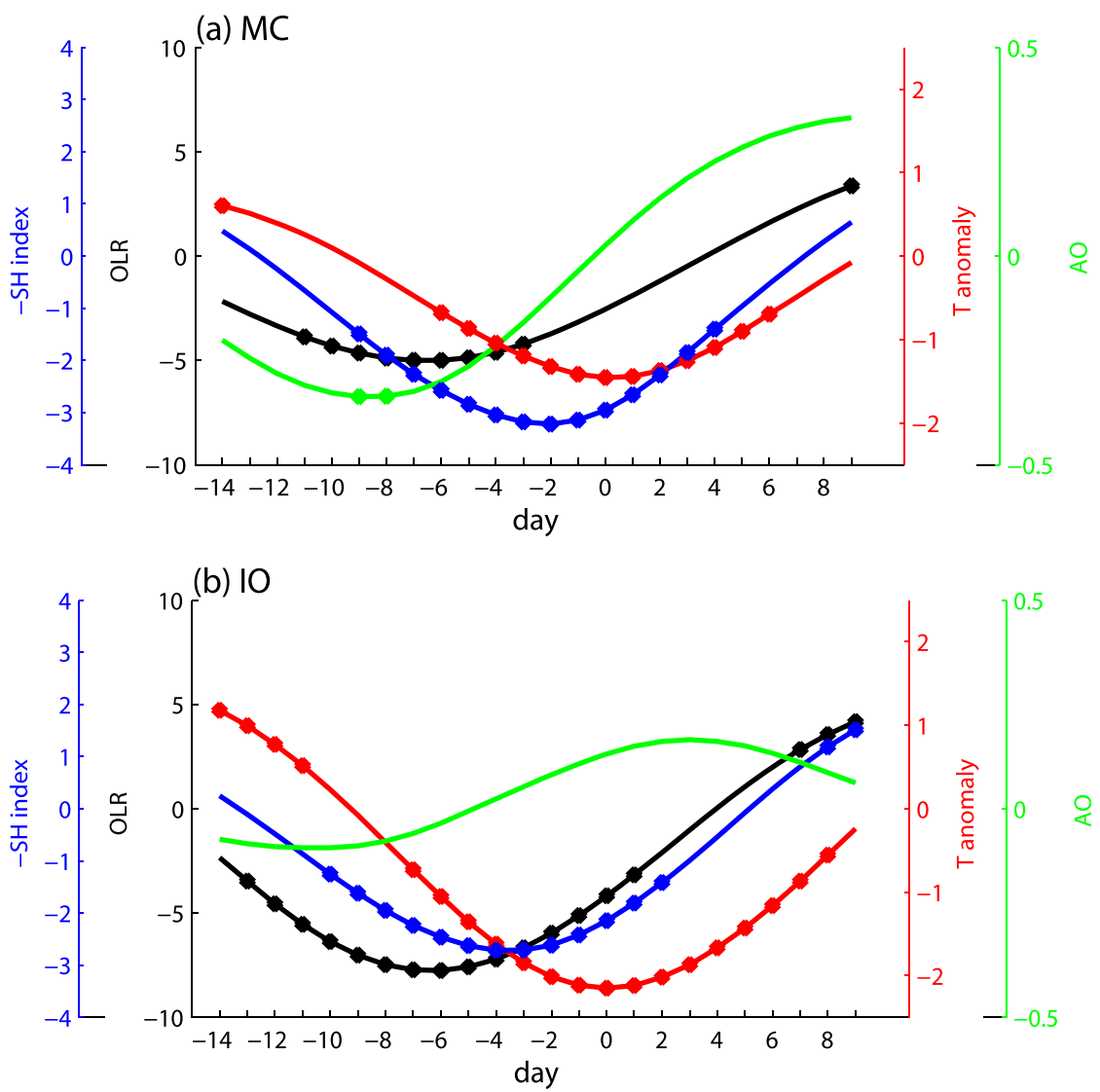

FIG. 7. Time evolution of regional mean surface air temperature anomalies $\left({ }^{\circ} \mathrm{C}\right)$ (red curve) over the region $20^{\circ}-40^{\circ} \mathrm{N}, 100^{\circ}-120^{\circ} \mathrm{E}$, showing OLR anomalies $\left(\mathrm{W} \mathrm{m}^{-2}\right)$ (black curve) over (a) the Maritime Continent $\left(15^{\circ} \mathrm{S}-15^{\circ} \mathrm{N}, 110^{\circ}-160^{\circ} \mathrm{E}\right)$ and (b) the Indian Ocean $\left(15^{\circ} \mathrm{S}-15^{\circ} \mathrm{N}\right.$, $50^{\circ}-100^{\circ} \mathrm{E}$ ), and the Siberian high index (hPa; blue curve) and the AO index (green curve) during the life cycle of the MC and IO convection-related cold events, respectively. Dots on the curves indicate anomalies significant at the $95 \%$ confidence level.

Fig. 2b of Lee et al. (2011). After day -12 , the wave pattern moves eastward, accompanied by the eastward propagation of anomalous tropical heating (Fig. 8b). The anomalous anticyclone over eastern coast of China, which is a Rossby wave response to anomalous tropical heating (Jin and Hoskins 1995; Matthews et al. 2004; Seo and Son 2012), intensifies (Fig. 8c) following the enhancement of convective heating over the Maritime Continent (Fig. 7a). Rossby wave activity fluxes originate from the anomalous anticyclone and propagate northeastward toward mid- and high-latitude Asia. Meanwhile, cyclonic anomalies over the midlatitude western Pacific are enhanced, which contributes to the deepening of the East Asian trough (Song et al. 2016) and the occurrence of cold events (Song and Wu 2017). The poleward Rossby wave pattern induced by anomalous convective heating over the Maritime Continent is similar to the result of linear model experiments by Abdillah et al. (2018) (see their Fig. 10b).
Another branch of Rossby wave activity fluxes is evident over the mid- to high latitudes after day -6 . The wave packets emit from the anticyclonic anomalies over northern Eurasia (Figs. 8c-e), which may be related to the negative phase of the AO (Fig. 7a) (Park et al. 2011). This equatorward Rossby wave energy dispersion also contributes to the deepening of the East Asian trough (Park et al. 2011). After day 0, the mid- to highlatitude wave train diminishes, while the poleward wave train trigged by anomalous tropical heating continues propagating downstream (Figs. $8 \mathrm{f}-\mathrm{h}$ ).

For the IO convection-related cold events, an anomalous cyclone-anticyclone-cyclone pattern is observed over mid- to high-latitude Eurasia on day -12 (Fig. 9a). Rossby wave fluxes emit from the anomalous cyclone over western Europe, indicating a downstream wave energy dispersion along the polar front jet toward East Asia. The mid- to high-latitude wave pattern moves southeastward, and the cyclonic anomalies over East 

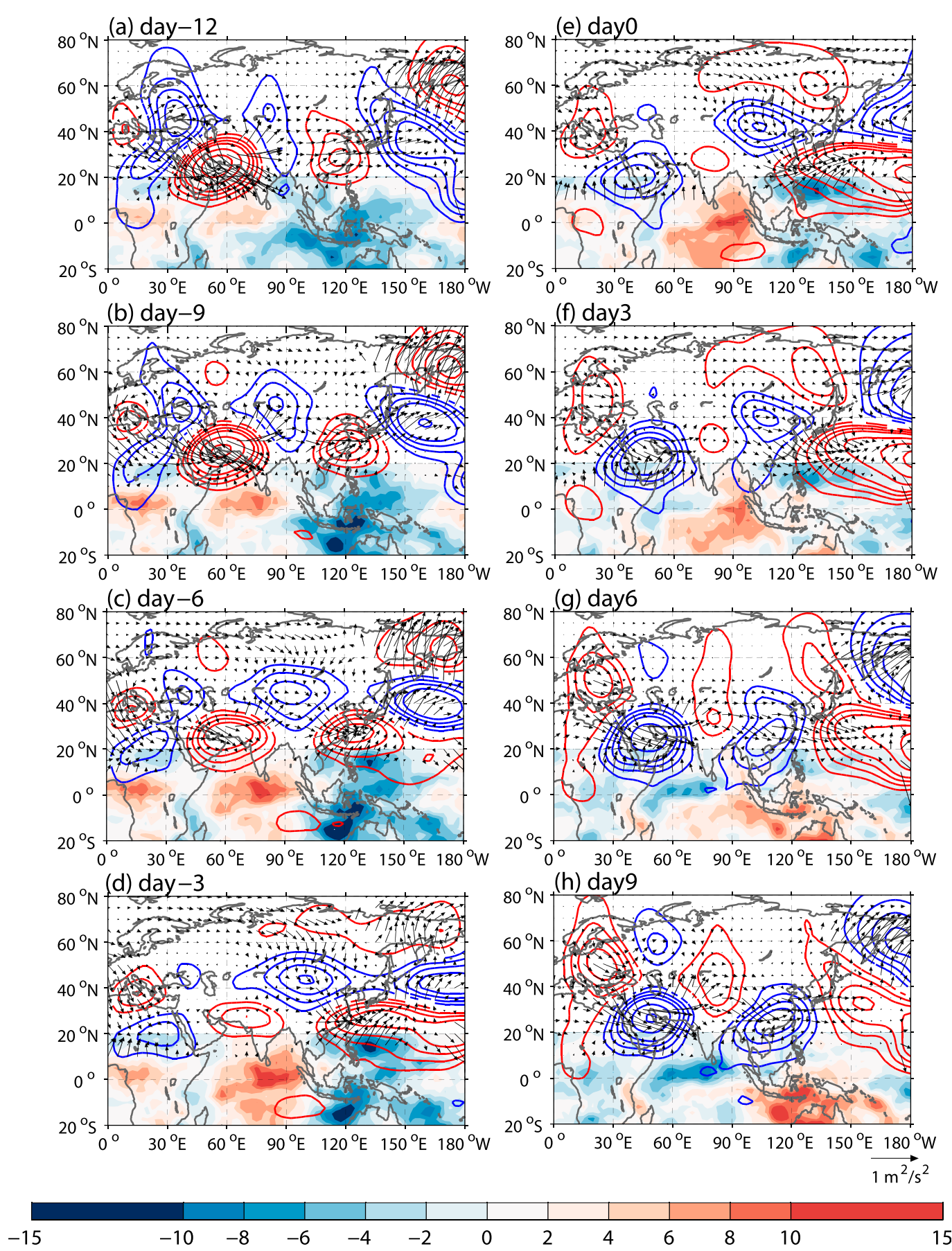

FIG. 8. Composite OLR anomalies (shading; $\mathrm{W} \mathrm{m}^{-2}$ ) between $20^{\circ} \mathrm{S}$ and $20^{\circ} \mathrm{N}$, streamfunction anomalies (contour; blue and red contours indicate negative and positive anomalies, respectively, intervals: $-8,-6,-4,-3,-2$, $-1,1,2,3,4,6$, and $\left.8 \times 10^{6} \mathrm{~m}^{2} \mathrm{~s}^{-2}\right)$, and wave activity fluxes $\left(\mathrm{m}^{2} \mathrm{~s}^{-2}\right)$ (vector; scale at bottom right) at $300 \mathrm{hPa}$ on days (a) -12 , (b) -9 , (c) -6 , (d) -3, (e) 0, (f) 3, (g) 6, and (h) 9 of MC convection-related intraseasonal cold events over eastern China.

Asia contribute to the deepening of the East Asian trough. Anticyclonic anomalies emerge over the northern Indian Ocean on day -9 , which is a Rossby wave response to anomalous tropical heating (Fig. 9b). The anomalous tropical heating is enhanced afterward, which induces the enhancement of poleward Rossby wave train (Figs. 9c,d). Like the MC convection-related cold events, the poleward wave energy dispersion 

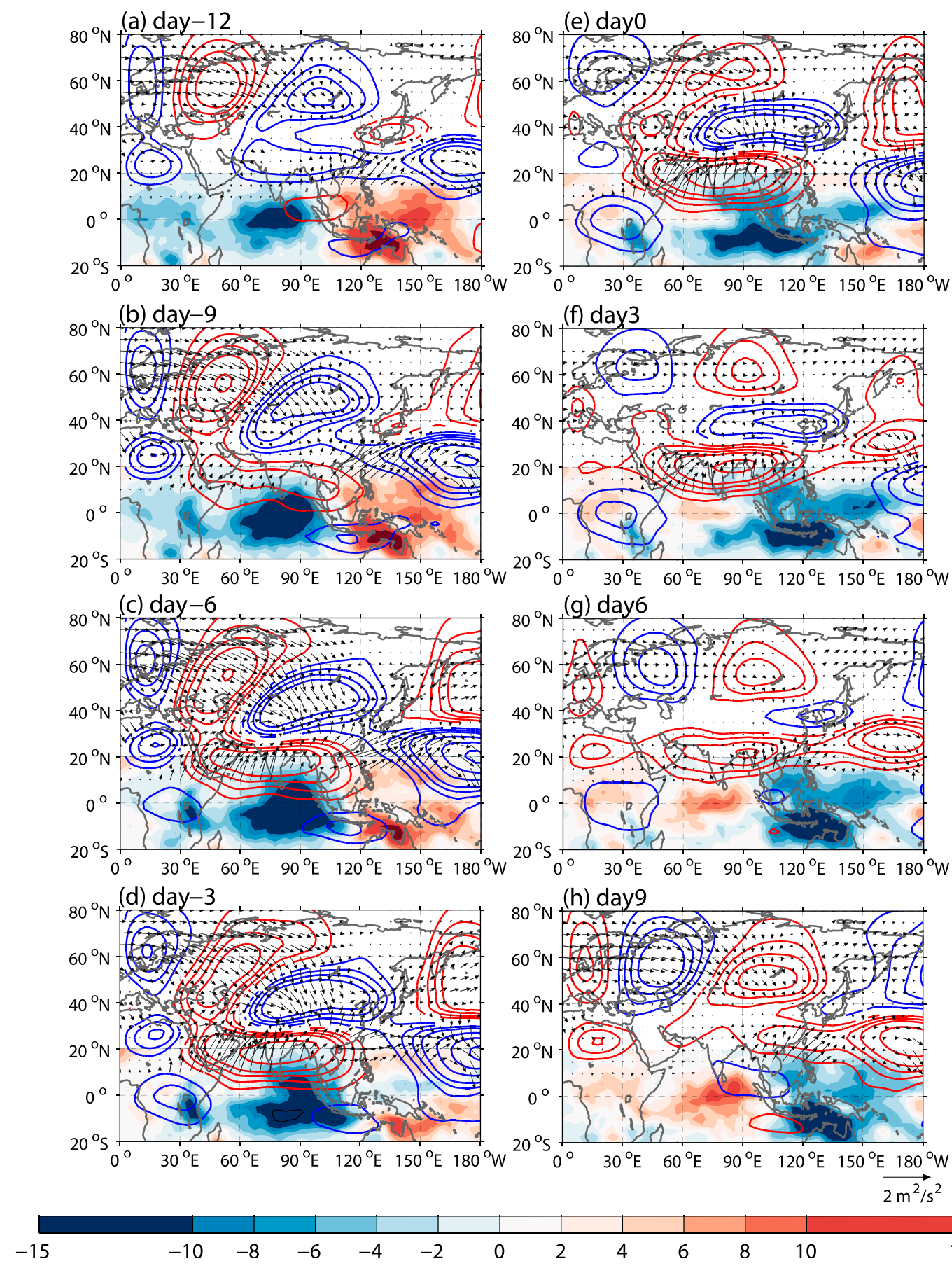

FIG. 9. As in Fig. 8, but for the IO convection-related cold events.

contributes to the development of the East Asian trough and the occurrence of the cold events (Abdillah et al. 2018). After day 0, the anomalous cyclone over East Asia is weakened (Figs. 9e-h), which corresponds to the diminishing of the cold anomalies.

The temporal lead-lag relationship between the tropical OLR anomalies and the Siberian high (Fig. 7) and the correspondence of the longitudinal locations of the tropical convection and the surface anticyclonic anomalies in Figs. 3-6 suggests a connection between anomalous tropical heating and the enhancement of the Siberian high. To provide evidence for this connection, we analyze the velocity potential and associated divergent winds at 200-hPa for MC and IO convection-related cold 
(a) day-12
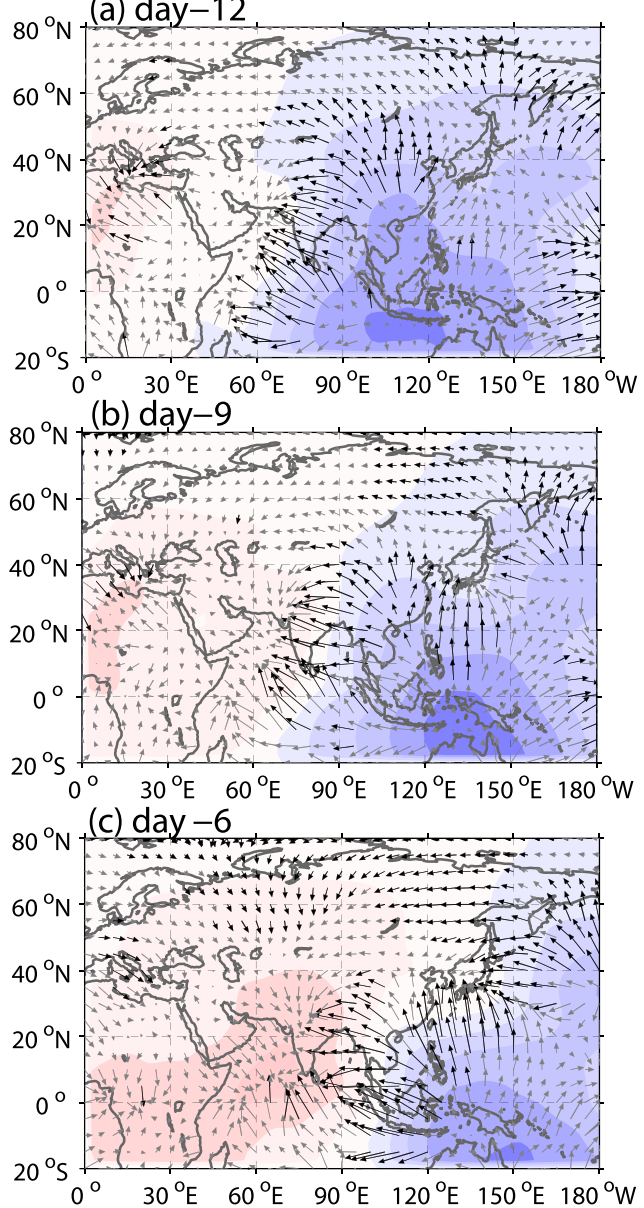

(d) day -3

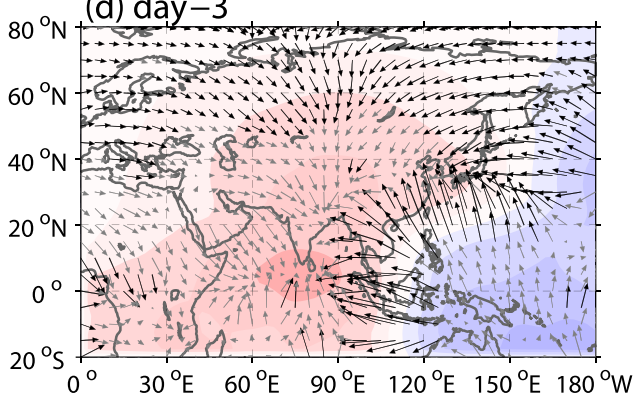

(e) day0

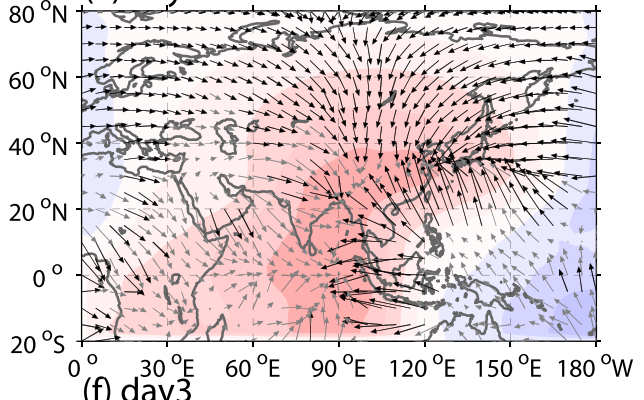

(f) day ${ }^{30} \mathrm{E}$

$20^{\circ} \mathrm{S} 0^{\circ} \quad 30^{\circ} \mathrm{E} \quad 60^{\circ} \mathrm{E} \quad 90^{\circ} \mathrm{E} \quad 120^{\circ} \mathrm{E} \quad 150^{\circ} \mathrm{E} \quad 180^{\circ} \mathrm{W}$
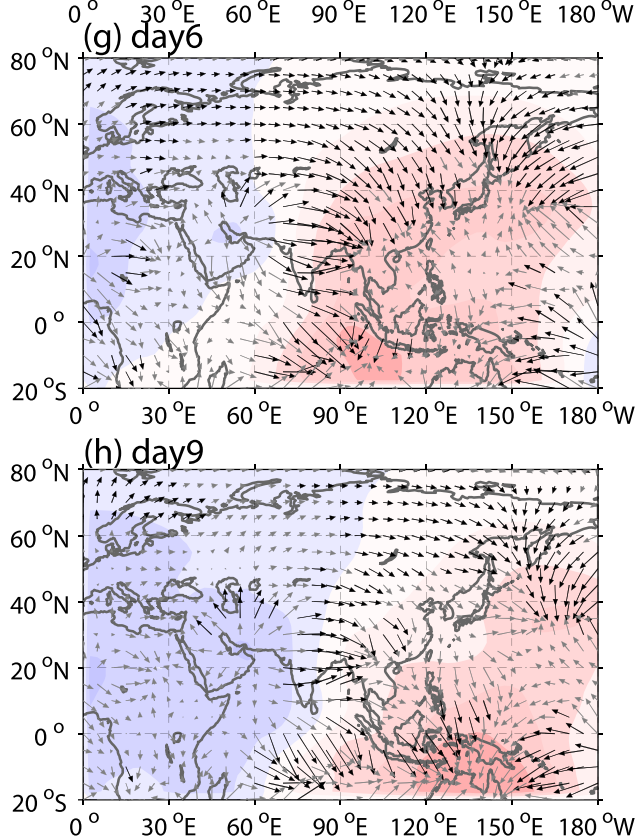

$\overrightarrow{1 \mathrm{~m} / \mathrm{s}}$

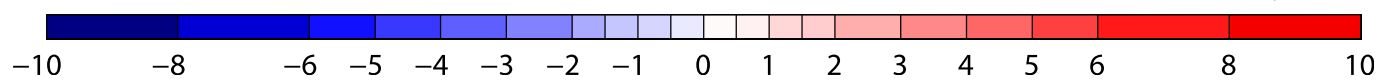

FIG. 10. Composite anomalies of velocity potential at $200 \mathrm{hPa}$ (shading; $\times 10^{6} \mathrm{~s}^{-1}$ ) and the corresponding divergent winds (vector; $\mathrm{m} \mathrm{s}^{-1}$; scale at bottom right) on days (a) -12 , (b) -9 , (c) -6 , (d) -3 , (e) 0 , (f) 3 , (g) 6 , and (h) 9 of MC convection-related intraseasonal cold events over eastern China. Black vectors denote divergent wind anomalies significant at the $95 \%$ confidence level.

events. The results, as presented below, indicate that anomalous tropical convection can enhance the Siberian high through modifying local meridional circulation.

For MC convection-related cold events, there is anomalous upper-level divergence over the Maritime Continent on day -12 (Fig. 10a), which corresponds to enhanced convective heating (Fig. 3a). Part of the anomalous upper-level divergent winds flow northward from the Maritime Continent to the midlatitudes south of the Lake Baikal (Fig. 10a). From day -9 to day -6 , anomalous 

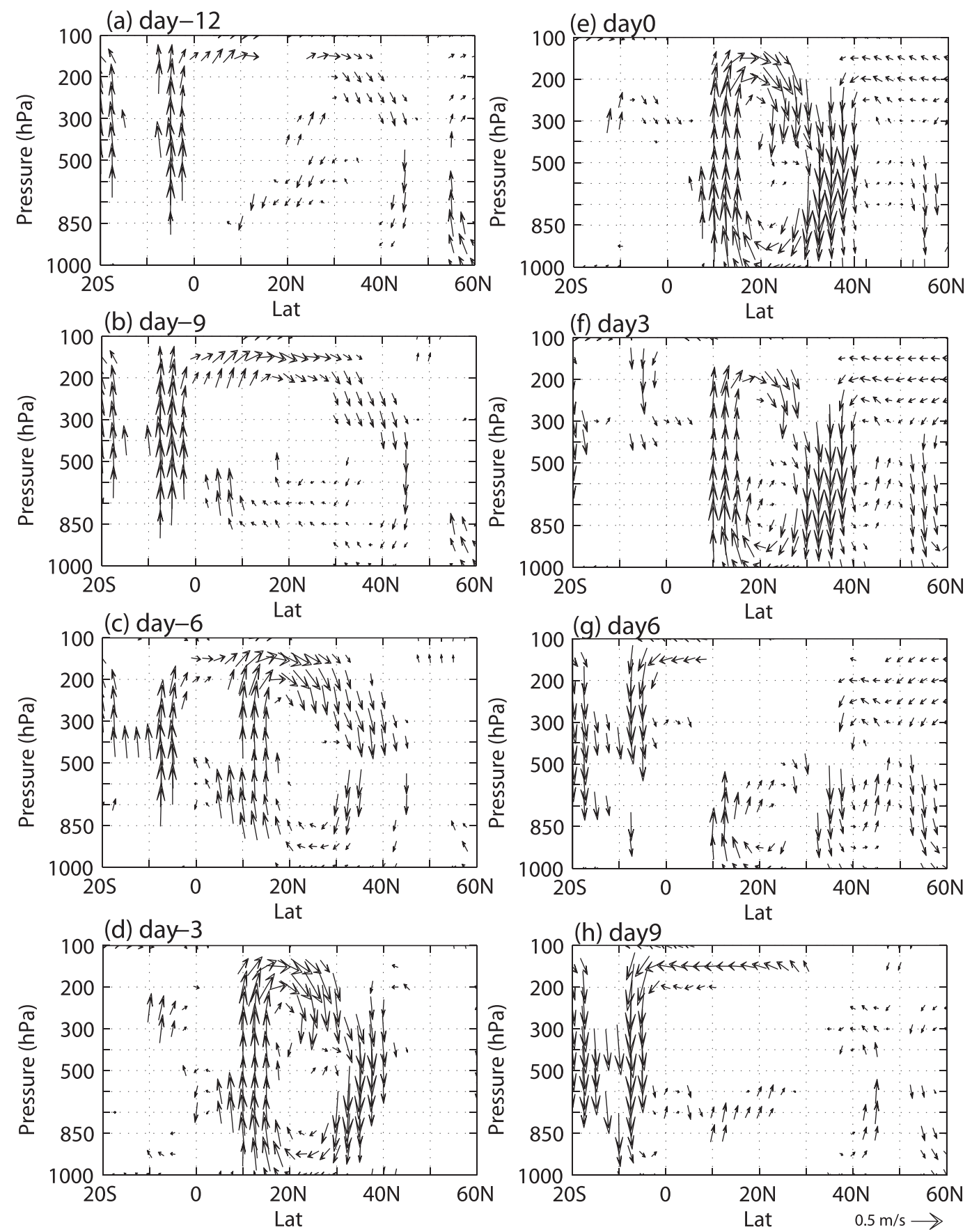

FIG. 11. Composite anomalies of vertical circulation consisting of divergent meridional wind $\left(\mathrm{m} \mathrm{s}^{-1}\right)$ and vertical $p$ velocity $\left(0.01 \mathrm{~Pa} \mathrm{~s}^{-1}\right)$ along $110^{\circ}-140^{\circ} \mathrm{E}$ on days (a) -12 , (b) -9 , (c) -6 , (d) -3 , (e) 0 , (f) 3 , (g) 6 , and (h) 9 of MC convection-related intraseasonal cold events over eastern China. Only the anomalies significant at the $95 \%$ confidence level are plotted.

upper-level divergent winds cover the southern part of surface anomalous anticyclone (Figs. 5b,c). This feature suggests an anomalous vertical circulation between the Maritime Continent and Siberia. Indeed, the latitudeheight cross section along $110^{\circ}-140^{\circ} \mathrm{E}$ shows clearly the development of an anomalous overturning circulation between the tropics and midlatitudes (Figs. 11a-c). Anomalous upward motion over the tropics and anomalous downward motion over the midlatitude around $45^{\circ} \mathrm{N}$ are connected by upper-level northward divergent 
winds and lower-level southward divergent winds. In addition, anomalous upward motion over the tropics leads anomalous downward motion over the midlatitudes. This indicates that anomalous convective heating over the Maritime Continent drives anomalous vertical circulation and descending motion over Siberia, contributing to the southeastward expansion of the Siberian high from day -9 to day -6 (Figs. 5a-c). The northern branch of the vertical cell retreats southward later on (Figs. 11c-e), which is accompanied by the southward extension of the Siberian high from day -6 to day 0 (Figs. $5 \mathrm{c}-\mathrm{e}$ ). With the eastward propagation of anomalous tropical convection (Figs. 3d-h), anomalous upper-level divergence moves eastward as well (Figs. 10d-h). After day 0, the Maritime Continent is covered by anomalous upper-level convergence (Figs. 10f-h), which is in accordance with the development of anomalous tropical cooling in situ (Figs. 3f-h). After day 0, with the weakening of anomalous tropical heating, the vertical cell diminishes as well (Fig. 11f-h).

For IO convection-related cold events, anomalous upper-level divergence is located over the tropical Indian Ocean on day -12 (Fig. 12a) where anomalous tropical convection situates (Fig. 4a). Anomalous upper-level divergent winds flow partly northward from the Indian Ocean toward midlatitude Siberia on day -9 and -6 (Figs. 12b,c). An anomalous overturning circulation develops between the tropics and midlatitudes along $50^{\circ}-80^{\circ} \mathrm{E}$, consisting of anomalous upward motion over the tropics, anomalous upper-level northward divergent winds, anomalous downward motion over the midlatitudes, and anomalous lower-level southward divergent winds (Figs. 13b-d). Anomalous downward motion over the midlatitudes lags anomalous upward motion over the tropics. The anomalous descending motion over Siberia contributes to the enhancement of surface anomalous anticyclone (Figs. 6b,c). This indicates that anomalous tropical heating triggers vertical circulation and enhances the Siberian high. Anomalous upper-level divergence moves eastward (Figs. 12d-h), following the eastward motion of anomalous tropical convection (Figs. 4d-h). With the switch of sign of OLR anomalies over the tropical Indian Ocean (Figs. 4f-h), anomalous upperlevel convergence develops and anomalous downward motion starts to dominate there (Figs. 12f-h). The anomalous descending over the midlatitudes is maintained till day 0 (Figs. 13c-e) and diminishes afterward (Figs. 13f-h).

Previous studies have suggested that anomalous tropical heating in association with the MJO can modify the local Hadley cell and influence the midlatitude climate (He et al. 2011; Seo et al. 2016). In the present study, we show that anomalous heating over both the Maritime
Continent and the tropical Indian Ocean can induce anomalous upper-level convergence and anomalous descending motion over the midlatitudes through anomalous meridional overturning circulation. The large-scale airmass convergence in the upper midtroposphere and the strong radiative cooling accompanying anomalous descending motion over Siberia contribute to the enhancement of the Siberian high (Ding and Krishnamurti 1987). Thus, anomalous convection over both the Maritime Continent and the tropical Indian Ocean can lead to cold temperatures over eastern China. The anomalous overturning circulation is located more eastward in MC convection-related cold events than in IO convectionrelated cold events. The upper-level northward divergent wind anomalies are stronger in IO convection-related cold events than in MC convection-related cold events. In IO convection-related cold events, the downward branch of the anomalous overturning circulation reaches the main body of the anomalous anticyclone on day -12 , which contributes to the enhancement and southeastward expansion of the Siberian high. In MC convectionrelated cold events, the northward divergent wind anomalies only reach the southern flank of the anomalous anticyclone on day -12 . They mainly contribute to the southeastward extension of the Siberian high.

\section{Summary and discussion}

The influence of anomalous convection over the tropical Indian Ocean during the MJO phases 2-3 on the cold anomalies over eastern China has been discussed in previous studies. In this study, we show that anomalous convective heating over the Maritime Continent can also induce intraseasonal cold events over eastern China. During the winters from $1979 / 80$ to $2015 / 16$, there were 16 and 22 intraseasonal cold events over eastern China related to anomalous convections over the Maritime Continent and the tropical Indian Ocean, respectively; in total 63 intraseasonal cold events. The main features and the processes of the MC and IO convection-related intraseasonal cold events are summarized below with the help of schematic diagrams in Fig. 14.

For the MC convection-related cold events, negative surface temperature anomalies move southward and intensify from the Lake Baikal whereas negative OLR anomalies are developing over the Maritime Continent starting 12 days before. At the same time, surface anticyclonic anomalies extend southeastward. About 6 days later, anticyclonic anomalies intrude into eastern China, accompanied by strong anomalous northerly winds along the southeastern flank of anomalous anticyclone, which brings cold air toward eastern China (Fig. 14a). 

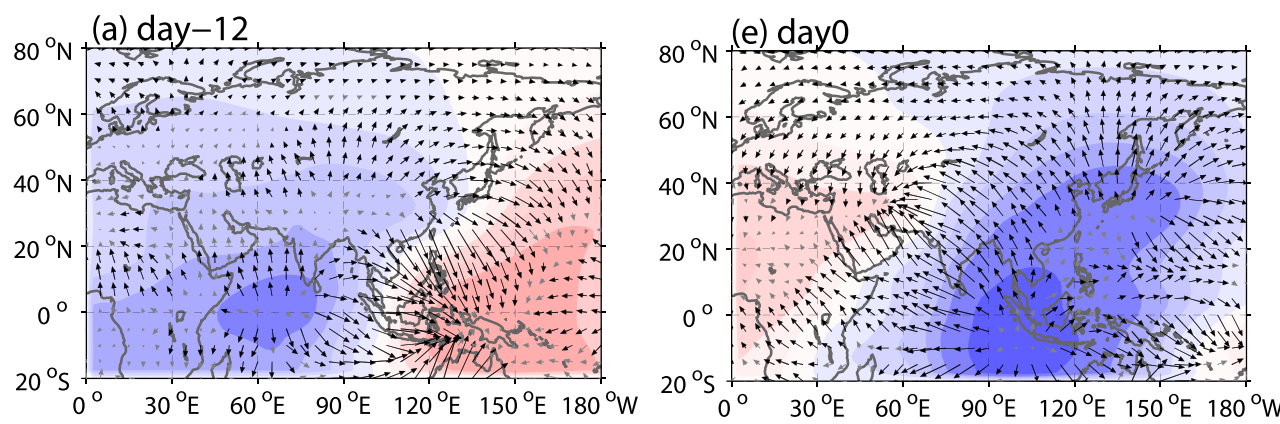

(b) day-9
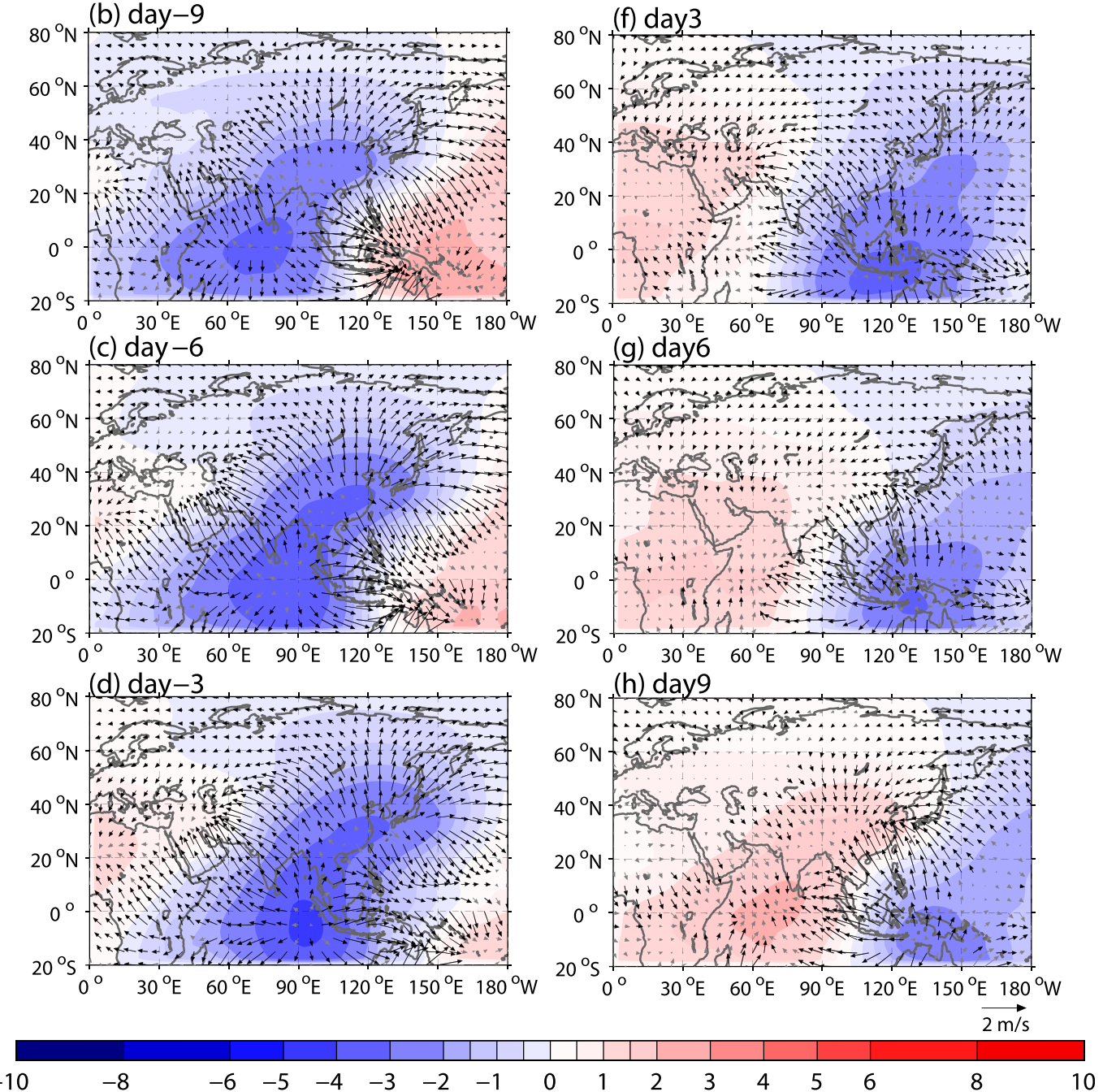

FIG. 12. As in Fig. 10, but for the IO convection-related cold events.

Meanwhile, in the upper troposphere, the poleward Rossby wave train triggered by anomalous convective heating over the Maritime Continent and the equatorward wave train related to negative $\mathrm{AO}$ both contribute to the deepening of the East Asian trough. This indicates that the anomalous convection over the Maritime Continent can work together with the negative $\mathrm{AO}$ in the occurrence of cold events over eastern China. The southeastward expansion of the Siberian high is linked to anomalous tropical heating over the Maritime Continent that induces an anomalous overturning circulation with anomalous descending over the midlatitudes (Fig. 14a).

For the IO convection-related cold events, negative surface temperature anomalies and surface anomalous anticyclone are situated more westward before their southeastward intrusion into eastern China, compared 

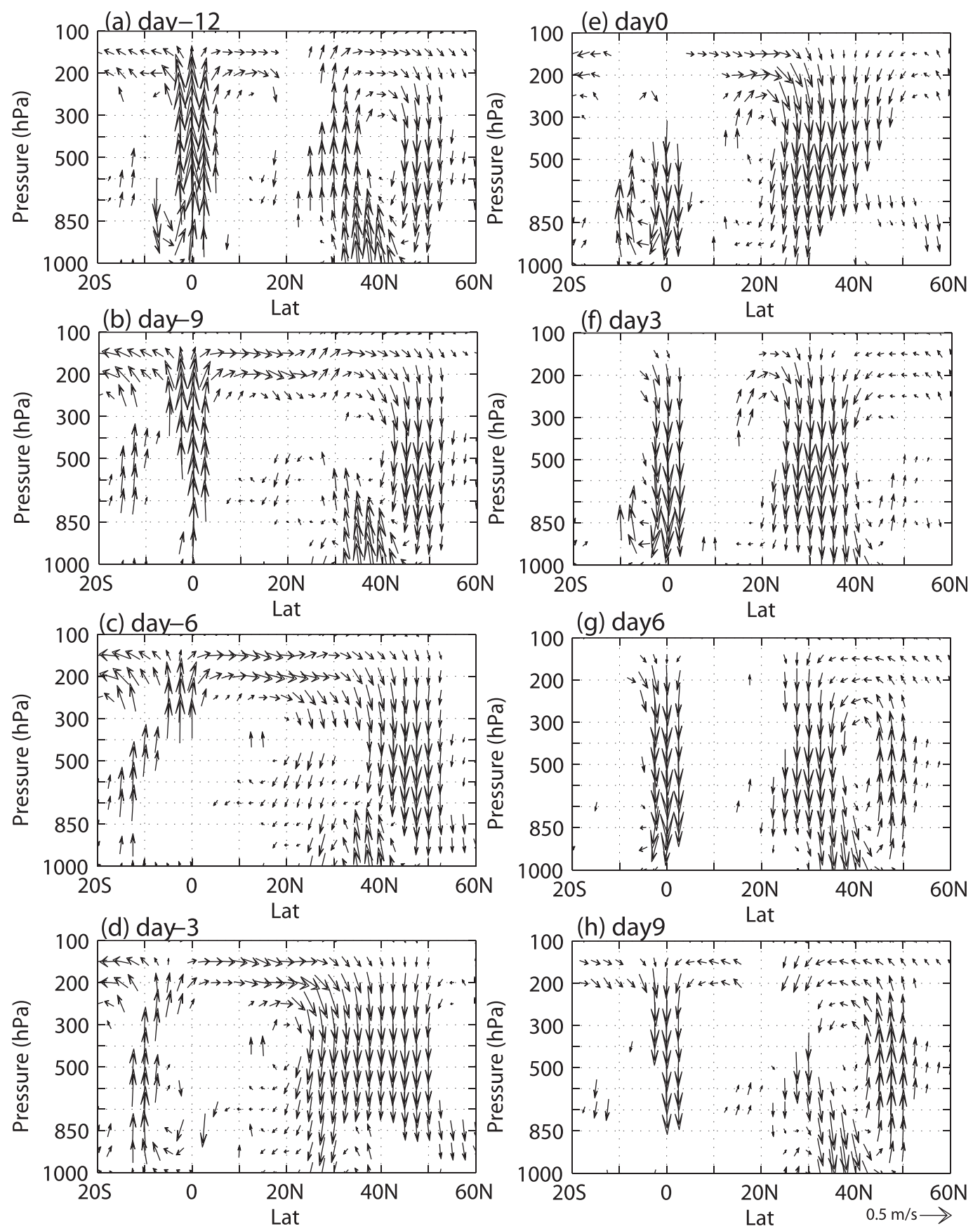

FIG. 13. As in Fig. 11, but along $50^{\circ}-80^{\circ} \mathrm{E}$ for IO convection-related intraseasonal cold events over eastern China.

to the MC convection-related cold events, with anomalous convective heating developing over the tropical Indian Ocean (Fig. 14b). The deepening of the East Asian trough is caused by both the tropospheric Rossby wave train propagating along the polar front and the poleward wave train trigged by anomalous convective heating over the tropical Indian Ocean. The relationship between the $\mathrm{AO}$ and the IO convection-related cold events is weak.
The anomalous heating over the tropical Indian Ocean induces an overturning circulation with anomalous upperlevel divergence and anomalous descending over Siberia, leading to the enhancement and southeastward extension of the Siberian high and the occurrence of cold anomalies over eastern China (Fig. 14b).

The enhancement/expansion of the Siberian high is related to anomalous tropical heating during both types 
(a) MC

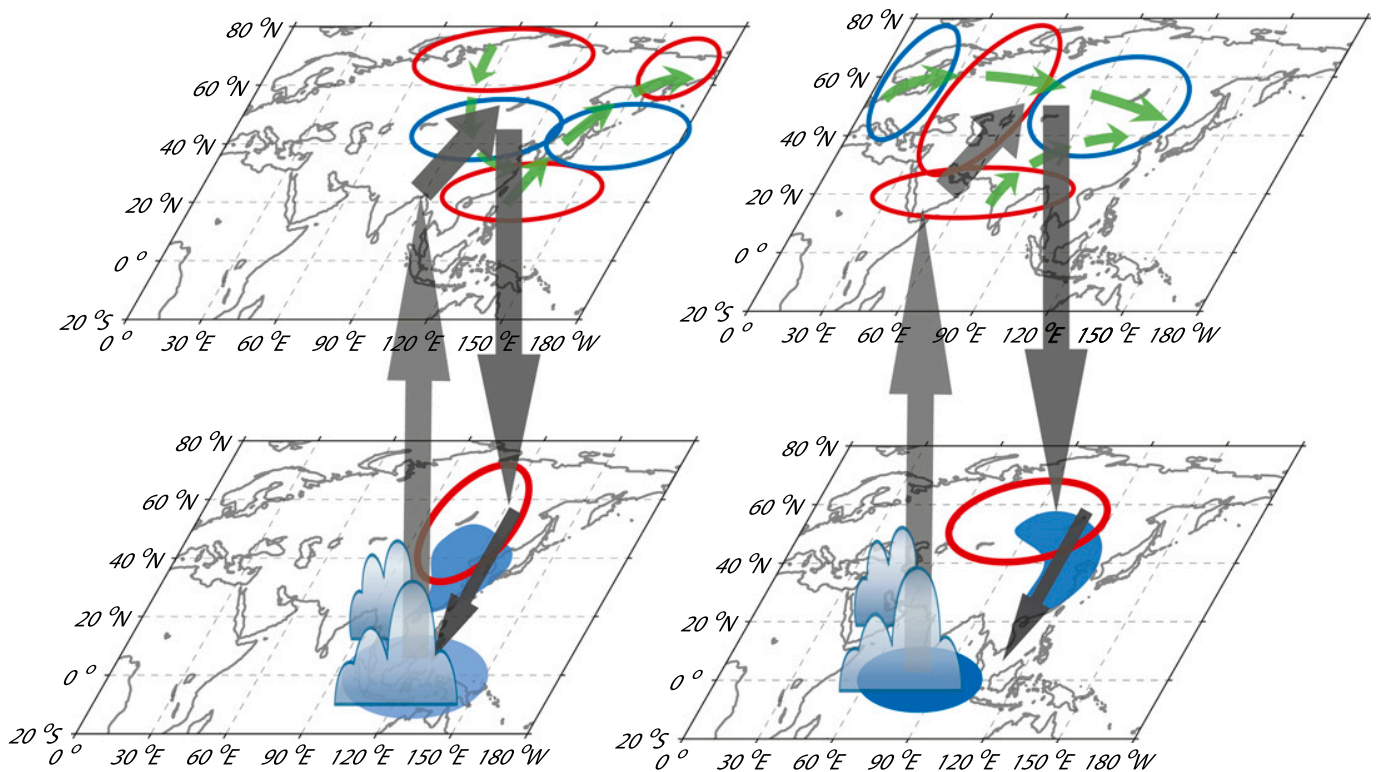

(b) 10

FIG. 14. Schematic diagrams showing the main features for the (a) MC and (b) IO convection-related cold events; the blue shadings and the clouds on the lower panel over the tropical region denote the convective heating over the Maritime Continent and Indian Ocean, respectively. The blue shadings on the lower panel over eastern China indicate cold surface temperature anomalies. The red contours on the lower panel over Siberia denote the Siberian high. The black arrows over East Asia indicate surface northerly winds. The upward and downward arrows in the middle of each subplot indicate ascending and descending motion on the southern and northern branches of the vertical circulation, respectively. The black arrows on the upper panel indicate northerly divergent winds anomalies. The red and blue contours over the Eurasian continent on the upper panel denote positive and negative streamfunction anomalies at $300 \mathrm{hPa}$. The green arrows indicate Rossby wave train fluxes at $300 \mathrm{hPa}$, respectively.

of cold events but over somewhat different longitudes corresponding to different longitudinal locations of anomalous tropical convection. Two effects may contribute to the enhancement/expansion of the Siberian high. One is large-scale airmass convergence in the upper midtroposphere. The other is the radiative cooling in association with anomalous descending that reduces cloudiness. The preferred region and intensity of these two effects depend upon the magnitude and location of anomalous tropical heating.

It should be noted that in MC convection-related cold events the negative AO is earlier than the OLR anomalies over the Maritime Continent by about 2 days (Fig. 7a), which is too short to separate the influence of the AO from the tropical convections. If the MC convection-related cold events are triggered by the AO alone, we should only observe the midlatitude wave train during the MC-related cold events, as shown by Park et al. (2011) in their Figs. 4a-c, 5a-c, and 6. But it is evident in Fig. 8 that the poleward wave energy dispersion triggered by the MC convection appears from day -9 to day 0 . Therefore, the negative $\mathrm{AO}$ and the convection anomalies over the Maritime Continent may work together in the occurrence of MC convectionrelated cold events over eastern China.

This study focuses on the development of intraseasonal cold events over eastern China related to anomalous convection over the Maritime Continent and the tropical Indian Ocean. Previous studies have suggested a relationship between the MJO and the stratospheric sudden warming (SSW) (Garfinkel et al. 2012) and the SSW may affect the winter climate over the Northern Hemisphere (Kodera et al. 2008). So, it may be possible that anomalous tropical convection influences first the stratospheric circulation and then the tropospheric climate. This possibility is worthy of investigation in the future. As noted in the introduction, anomalous convection over the Maritime Continent may be followed by both cold and warm events over eastern China. An issue is why two opposite situations occur under similar anomalous tropical convection. This issue needs to be addressed in future studies.

Acknowledgments. We appreciate comments from two anonymous reviewers that have helped the improvement of this manuscript. This study is supported by the 
National Natural Science Foundation of China Grants 41705063, 41530425, 41775080, 41721004, and 41475081. The NCEP Reanalysis 2 data were obtained from ftp:// ftp.cdc.noaa.gov/.

\section{REFERENCES}

Abdillah, M. R., Y. Kanno, and T. Iwasaki, 2018: Tropicalextratropical interactions associated with East Asian cold air outbreaks. Part II: Intraseasonal variation. J. Climate, 31, 473-490, https://doi.org/10.1175/JCLI-D-17-0147.1.

Baxter, S., S. Weaver, J. Gottschalck, and Y. Xue, 2014: Pentad evolution of wintertime impacts of the Madden-Julian oscillation over the contiguous United States. J. Climate, 27, 7356-7367, https://doi.org/10.1175/JCLI-D-14-00105.1.

Bueh, C., N. Shi, and Z. Xie, 2011: Large-scale circulation anomalies associated with persistent low temperature over southern China in January 2008. Atmos. Sci. Lett., 12, 273-280, https:// doi.org/10.1002/asl.333.

Ding, Y., 1990: Build-up, air mass transformation and propagation of Siberian high and its relations to cold surge in East Asia. Meteor. Atmos. Phys., 44, 281-292, https://doi.org/10.1007/ bf01026822.

_, and T. N. Krishnamurti, 1987: Heat budget of the Siberian high and the winter monsoon. Mon. Wea. Rev., 115, 2428-2449, https:// doi.org/10.1175/1520-0493(1987)115<2428:HBOTSH>2.0.CO;2.

Garfinkel, C. I., S. B. Feldstein, D. W. Waugh, C. Yoo, and S. Lee, 2012: Observed connection between stratospheric sudden warmings and the Madden-Julian Oscillation. Geophys. Res. Lett., 39, L18807, https://doi.org/10.1029/2012GL053144.

Gong, D.-Y., S.-W. Wang, and J.-H. Zhu, 2001: East Asian winter monsoon and Arctic Oscillation. Geophys. Res. Lett., 28, 2073-2076, https://doi.org/10.1029/2000GL012311.

He, J., H. Lin, and Z. Wu, 2011: Another look at influences of the Madden-Julian oscillation on the wintertime East Asian weather. J. Geophys. Res., 116, D03109, https://doi.org/ 10.1029/2010JD014787.

Jeong, J.-H., and C.-H. Ho, 2005: Changes in occurrence of cold surges over East Asia in association with Arctic Oscillation. Geophys. Res. Lett., 32, L14704, https://doi.org/10.1029/ 2005 GL023024.

Jin, F., and B. J. Hoskins, 1995: The direct response to tropical heating in a baroclinic atmosphere. J. Atmos. Sci., 52, 307-319, https://doi.org/10.1175/1520-0469(1995)052<0307:TDRTTH> 2.0.CO;2.

Kanamitsu, M., W. Ebisuzaki, J. Woollen, S.-K. Yang, J. J. Hnilo, M. Fiorino, and G. L. Potter, 2002: NCEP-DOE AMIP-II Reanalysis (R-2). Bull. Amer. Meteor. Soc., 83, 1631-1644, https://doi.org/10.1175/BAMS-83-11-1631.

Kodera, K., H. Mukougawa, and S. Itoh, 2008: Tropospheric impact of reflected planetary waves from the stratosphere. Geophys. Res. Lett., 35, L16806, https://doi.org/10.1029/2008GL034575.

Lee, S., T. Gong, N. Johnson, S. B. Feldstein, and D. Pollard, 2011: On the possible link between tropical convection and the Northern Hemisphere Arctic surface air temperature change between 1958 and 2001. J. Climate, 24, 4350-4367, https:// doi.org/10.1175/2011JCLI4003.1.

Lin, H., 2015: Subseasonal variability of North American wintertime surface air temperature. Climate Dyn., 45, 1137-1155, https://doi.org/10.1007/s00382-014-2363-6.

— oscillation on Canadian wintertime surface air temperature.
Mon. Wea. Rev., 137, 2250-2262, https://doi.org/10.1175/ 2009MWR2831.1.

Madden, R. A., and P. R. Julian, 1971: Detection of a 40-50 day oscillation in the zonal wind in the tropical Pacific. J. Atmos. Sci., 28, 702-708, https://doi.org/10.1175/1520-0469(1971) 028<0702:DOADOI >2.0.CO;2.

—_, and — 1972: Description of global-scale circulation cells in the tropics with a 40-50 day period. J. Atmos. Sci., 29, 1109-1123, https://doi.org/10.1175/1520-0469(1972)029<1109: DOGSCC $>2.0 . \mathrm{CO} ; 2$.

Matthews, A. J., B. J. Hoskins, and M. Masutani, 2004: The global response to tropical heating in the Madden-Julian oscillation during the northern winter. Quart. J. Roy. Meteor. Soc., 130, 1991-2011, https://doi.org/10.1256/qj.02.123.

Panagiotopoulos, F., M. Shahgedanova, A. Hannachi, and D. B. Stephenson, 2005: Observed trends and teleconnections of the Siberian high: A recently declining center of action. J. Climate, 18, 1411-1422, https://doi.org/10.1175/JCLI3352.1.

Park, T.-W., C.-H. Ho, S. Yang, and J.-H. Jeong, 2010: Influences of Arctic Oscillation and Madden-Julian Oscillation on cold surges and heavy snowfalls over Korea: A case study for the winter of 2009-2010. J. Geophys. Res., 115, D23122, https:// doi.org/10.1029/2010JD014794.

- - - , and ——, 2011: Relationship between the Arctic Oscillation and cold surges over East Asia. J. Climate, 24, 68-83, https://doi.org/10.1175/2010JCLI3529.1.

Seo, K.-H., and S.-W. Son, 2012: The global atmospheric circulation response to tropical diabatic heating associated with the Madden-Julian oscillation during northern winter. J. Atmos. Sci., 69, 79-96, https://doi.org/10.1175/ 2011JAS3686.1.

- - H.-J. Lee, and D. M. W. Frierson, 2016: Unraveling the teleconnection mechanisms that induce wintertime temperature anomalies over the Northern Hemisphere continents in response to the MJO. J. Atmos. Sci., 73, 3557-3571, https:// doi.org/10.1175/JAS-D-16-0036.1.

Shoji, T., Y. Kanno, T. Iwasaki, and K. Takaya, 2014: An isentropic analysis of the temporal evolution of East Asian cold air outbreaks. J. Climate, 27, 9337-9348, https://doi.org/10.1175/ JCLI-D-14-00307.1.

Song, L., and R. Wu, 2017: Processes for occurrence of strong cold events over eastern China. J. Climate, 30, 9247-9266, https:// doi.org/10.1175/JCLI-D-16-0857.1.

— winter cold temperature anomalies in positive and negative phases of the Arctic Oscillation. J. Geophys. Res. Atmos., 123, 8518-8537, https://doi.org/10.1029/2018JD028343.

— L. L. Wang, W. Chen, and Y. Zhang, 2016: Intraseasonal variation of the strength of the East Asian trough and its climatic impacts in boreal winter. J. Climate, 29, 2557-2577, https:// doi.org/10.1175/JCLI-D-14-00834.1.

Takaya, K., and H. Nakamura, 2001: A formulation of a phaseindependent wave-activity flux for stationary and migratory quasigeostrophic eddies on a zonally varying basic flow. J. Atmos. Sci., 58, 608-627, https://doi.org/10.1175/15200469(2001)058<0608:AFOAPI >2.0.CO;2.

$\longrightarrow$, and - 2005a: Geographical dependence of upper-level blocking formation associated with intraseasonal amplification of the Siberian high. J. Atmos. Sci., 62, 4441-4449, https:// doi.org/10.1175/JAS3628.1.

—, and $-2005 \mathrm{~b}$ : Mechanisms of intraseasonal amplification of the cold Siberian high. J. Atmos. Sci., 62, 4423-4440, https:// doi.org/10.1175/JAS3629.1. 
and -2013 : Interannual variability of the East Asian winter monsoon and related modulations of the planetary waves. J. Climate, 26, 9445-9461, https://doi.org/10.1175/ JCLI-D-12-00842.1.

Thompson, D. W. J., and J. M. Wallace, 1998: The Arctic oscillation signature in the wintertime geopotential height and temperature fields. Geophys. Res. Lett., 25, 1297-1300, https://doi.org/ 10.1029/98GL00950.

—_, and —, 2000: Annular modes in the extratropical circulation. Part I: Month-to-month variability. J. Climate, 13, 1000-1016, https://doi.org/10.1175/1520-0442(2000)013<1000: AMITEC $>2.0 . \mathrm{CO} ; 2$.

Wang, L., and W. Chen, 2010: Downward Arctic Oscillation signal associated with moderate weak stratospheric polar vortex and the cold December 2009. Geophys. Res. Lett., 37, L09707, https://doi.org/10.1029/2010GL042659.

Watanabe, M., 2004: Asian jet waveguide and a downstream extension of the North Atlantic Oscillation. J. Climate, 17, 46744691, https://doi.org/10.1175/JCLI-3228.1.

Wen, M., S. Yang, A. Kumar, and P. Zhang, 2009: An analysis of the large-scale climate anomalies associated with the snowstorms affecting China in January 2008. Mon. Wea. Rev., 137, 1111-1131, https://doi.org/10.1175/2008MWR2638.1.
Wheeler, M. C., and H. H. Hendon, 2004: An all-season real-time multivariate MJO Index: Development of an index for monitoring and prediction. Mon. Wea. Rev., 132, 1917-1932, https:// doi.org/10.1175/1520-0493(2004)132<1917:AARMMI>2.0.CO;2.

Wu, B., and J. Wang, 2002: Winter Arctic Oscillation, Siberian high and East Asian winter monsoon. Geophys. Res. Lett., 29, 1897, https://doi.org/10.1029/2002GL015373.

Wu, Z., J. Li, B. Wang, and X. Liu, 2009: Can the Southern Hemisphere annular mode affect China winter monsoon? J. Geophys. Res., 114, D11107, https://doi.org/10.1029/2008JD011501.

Yoo, C., S. Lee, and S. B. Feldstein, 2012: Mechanisms of Arctic surface air temperature change in response to the MaddenJulian oscillation. J. Climate, 25, 5777-5790, https://doi.org/ 10.1175/JCLI-D-11-00566.1.

Zhang, Y., K. R. Sperber, and J. S. Boyle, 1997: Climatology and interannual variation of the East Asian winter monsoon: $\mathrm{Re}$ sults from the 1979-95 NCEP/NCAR reanalysis. Mon. Wea. Rev., 125, 2605-2619, https://doi.org/10.1175/1520-0493(1997) 125<2605:CAIVOT $>2.0$. CO;2.

Zhou, W., J. C. L. Chan, W. Chen, J. Ling, J. G. Pinto, and Y. Shao, 2009: Synoptic-scale controls of persistent low temperature and icy weather over southern China in January 2008. Mon. Wea. Rev., 137, 3978-3991, https://doi.org/10.1175/2009MWR2952.1. 